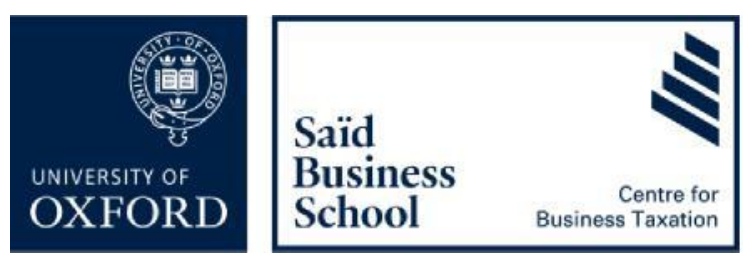

\title{
The Behavioral Elasticity of Tax Revenue
}

\section{WP 20/05}

June 2020

Daniel J. Hemel and David A. Weisbach The University of Chicago Law School 


\title{
The Behavioral Elasticity of Tax Revenue
}

\author{
Daniel J. Hemel and David A. Weisbach ${ }^{\dagger}$
}

Draft of February 8, 2020

\begin{abstract}
This article presents a new measure of the efficiency consequences of tax policies and explains how this new measure can shed light on a wide range of tax law debates. We build upon the "elasticity of taxable income" approach pioneered by public finance scholars over the last quarter century and extend that approach to address complex tax systems with multiple rates, multiple bases, and administrative and compliance costs. The resulting measure - the behavioral elasticity of taxable revenue, or BETR - captures the change in real resources available to society caused by any marginal change in tax rates, the tax base, or tax enforcement. We argue that the BETR can serve as a guide to a broad array of tax policy puzzles, and we illustrate the BETR's utility by applying it to questions such as the proper treatment of mixed personal/business expenses and the optimal mix of audits, reporting requirements, and penalties. We also consider the relationship between the BETR and the distributional aims of tax law. While the BETR is a measure of efficiency and not distribution, the BETR can aid policymakers in deciding both how much to redistribute and how to accomplish distributional objectives most efficiently. We end with reflections on the implications of the BETR for the design of non-tax legal rules.
\end{abstract}

+ The University of Chicago Law School. We thank participants at the University of Chicago Law School Works-in-Progress Workshop, the University of Virginia Invitational Tax Conference, the Stanford Law School Tax Policy Seminar, Joe Bankman, Thomas Brennan, Dan Kessler, Jacob Goldin, and Louis Kaplow for comments on earlier drafts; Ethan Ames for research assistance; and the Douglas Clark and Ruth Ann McNees Faculty Research Fund for financial support. 


\section{Introduction}

What is the proper scope of the tax base? At what rates should items in the tax base be taxed? How much should the government spend on different tax administration and enforcement activities, and how much should it require taxpayers to incur in compliance costs? And how do these base and enforcement choices relate to distributional concerns? These are the central questions for the design of a tax system. Each is the subject of a vast literature, both in law and in economics. Variants of these questions fill the syllabi of introductory income tax courses and upper-level tax policy seminars.

How a polity resolves these questions will have enormous implications for the wellbeing of its members. When the costs of tax collection are low, governments can more easily provide public goods and redistribute resources to low-income households. In one view, the success of Scandinavian countries in raising the standard of living for their citizens and minimizing inequality stems from the efficiency of their tax systems, which enable greater government spending and redistribution. ${ }^{1}$ Conversely, when the costs of tax collection are high, governments will struggle to satisfy their citizens' needs. The failure of many developing-country governments to deliver basic services and foster economic growth can be attributed in no small part to the inefficiency of those countries' tax systems. ${ }^{2}$

In the United States, widening wealth and income inequality raise the stakes of debates over tax base definition and tax enforcement. For example,

${ }^{1}$ See Henrik Jacobsen Kleven, How Can Scandinavians Tax So Much?, 28 J. Econ. PersP. 77 (2014).

${ }^{2}$ See Roger Gordon \& Wei Li, Tax Structures in Developing Countries: Many Puzzles and a Possible Explanation, 93 J. PuB. Econ. 855 (2009); Roy W. Bahl \& Richard M. Bird, Tax Policy in Developing Countries: Looking Back—and Forward, 61 NAT'L TAX J. 279 (2008). 
proposals to tax wealth or to impose high rates of tax on high incomes will fail to achieve their objectives if enforcement is weak. Conversely, efficient and effective tax policies and enforcement mechanisms will mitigate the tradeoff between equity and economic growth that redistributive taxes inevitably entail. Wealth and income inequality - which President Obama described as a "defining challenge of our time"3-largely boil down to a challenge of tax system design.

While the problems of tax system design seem disparate and complex, we argue here that there is a unified way to address them. In particular, we propose a tool for analyzing problems of tax system design, which we call the Behavioral Elasticity of Tax Revenue, or the BETR. The BETR is a measure of the efficiency implications of taxation. It allows tax laws and policies to be measured and compared using a unified metric. It allows us to determine the proper scope of the tax base, optimal enforcement policies, and other central variables of the tax system. The BETR also allows policymakers to identify the most efficient mechanisms for redistributing income and thus plays a central role in efforts to address poverty and income inequality.

The BETR is a modified and extended version of a tool that has taken over the field of public economics in recent years: the elasticity of taxable income, or ETI. ${ }^{4}$ The basic intuition underlying the ETI is straightforward: Imagine that the tax rate is 30 percent and that a taxpayer's hourly wage in the formal economy is $\$ 10$. The taxpayer will therefore allocate her time so

${ }^{3}$ Jim Kuhnhenn, Obama Says Income Inequality Is Defining Challenge for U.S., PBS NEwsHour (Dec. 4, 2013), https://www.pbs.org/newshour/politics/obama-set-to-speak-onincome-gap-between-rich-and-poor.

${ }^{4}$ The ETI in its modern form was first advanced by Martin Feldstein in two articles published in the late 1990s. Martin Feldstein, The Effect of Marginal Tax Rates on Taxable Income: A Panel Study of the 1986 Tax Reform Act, 103 J. Pol. Econ. 551 (1995); Martin Feldstein, Tax Avoidance and the Deadweight Loss of the Income Tax, 81 REv. Econ. STAT. 674 (1999). 
that she is indifferent between (a) working an additional hour in the formal economy, thus earning $\$ 10$ before taxes and $\$ 7$ after taxes, and (b) devoting an additional hour to alternative pursuits from which she derives $\$ 7$ of value. Those alternative pursuits could include work in the informal economy (i.e., the black market), household production, or leisure.

Although the taxpayer is indifferent as to how she spends the next hour, society is not. Society is $\$ 3$ better off when the taxpayer chooses to allocate an additional hour to work in the formal economy because she then pays an additional $\$ 3$ in taxes, which can be used to finance public goods or to lower taxes. Symmetrically, society is $\$ 3$ worse off when the taxpayer chooses to allocate one fewer hour to work in the formal economy because then it has $\$ 3$ less in revenue. Importantly, to measure the impact of a tax change on the resources available to society, we do not need to know precisely how taxpayers reallocate their time (e.g., whether they shift into or out of the informal economy, or whether they engage in more or less household production, or whether they devote more or less time to leisure). All we need to know is how their reported taxable income responds to the change-that is, the elasticity of taxable income. By multiplying the change in taxable income by the tax rate, we can calculate the efficiency consequences of the tax change.

The ETI transforms daunting empirical questions into tractable ones. Consider, for example, the calculation of the "excess burden," or "deadweight loss," of an increase in tax rates (i.e., the reduction in the resources available to society due to tax-induced distortions). Individuals may respond to tax rate increases in all sorts of ways. Some may choose less remunerative jobs that are rewarding in other respects. Some may shift to black market activities. Some may spend more time on the couch watching television, or they may perform more household tasks themselves (e.g., cooking, cleaning, and childcare) rather than hiring housekeepers or babysitters. Some may not change their time allocation at all but may report less of their income due to avoidance or evasion. It is impossible for any researcher to observe all of these potential responses. Researchers can, however, observe the increase or 
decrease in reported taxable income following the tax change. The "magic," so to speak, of the ETI is that the effect on reported taxable income (or, more precisely, the effect on reported taxable income times the tax rate) is all a researcher needs to know to calculate-to a first approximation-the efficiency consequences of a tax change.

Over the last 20 years, the ETI has allowed economists to make substantial advances in understanding the economics of taxation. ${ }^{5}$ With the

${ }^{5}$ Emmanuel Saez, Joel Slemrod, and Seth Giertz provide an overview of the use of the ETI in economics. Emmanuel Saez \& Joel Slemrod \& Seth H. Giertz, The Elasticity of Taxable Income with Respect to Marginal Tax Rates: A Critical Review, 50 J. ECon. LIT. 3 (2012). For a sample of the literature in economics using or estimating the elasticity of taxable income, see Gerald Auten \& Robert Carroll, The Effect of Income Taxes on Household Income, 81 REv. Econ. STAT. 681 (1999); Raj Chetty, Is the Taxable Income Elasticity Sufficient to Calculate Deadweight Loss? The Implications of Evasion and Avoidance, 1 Am. Econ. J. Econ. PoL'Y 31 (2009); Michael P. Devereux, Li Liu \& Simon Loretz, The Elasticity of Corporate Taxable Income: New Evidence from UK Tax Records, 6 Am. ECoN. J. ECON. PoL'Y. 19 (2014); Peter Diamond \& Emmanuel Saez, The Case for a Progressive Tax: From Basic Research to Policy Recommendations, 25 J. Econ. PersP. 165 (2011); Seth H. Giertz, The Elasticity of Taxable Income over the 1980s and 1990s, 60 NAT'L TAX J. 743 (2007); Seth H. Giertz, The Elasticity of Taxable Income During the 1990s: New Estimates and Sensitivity Analyses, 77 SoutH. Econ. J. 406 (2010); Jon Gruber \& Emmanuel Saez, The Elasticity of Taxable Income: Evidence and Implications, 84 J. Pub. Econ. 1 (2002); Nathaniel Hendren, The Policy Elasticity, 30 TAX PoL'y Econ. 51 (2016); Michael Keen \& Joel Slemrod, Optimal Tax Administration, 152 J. Pub. Econ. 133 (2017); Wojciech Kopczuk, Tax Bases, Tax Rates and the Elasticity of Reported Income, 89 J. Pub. Econ. 2093 (2005); Thomas Piketty, Emmanuel Saez \& Stefanie Stantcheva, Optimal Taxation of Top Labor Incomes: A Tale of Three Elasticities, 6 AM. ECoN. J. Econ. PoL'Y. 230 (2014); Emmanuel Saez, Using Elasticities to Derive Optimal Income Tax Rates, 68 REv. Econ. STUD. 205 (2001); Emmanuel Saez, Reported Incomes and Marginal Tax Rates, 1960-2000: Evidence and Policy Implications, 18 TAX PoL'y Econ. 117 (2004); Joel Slemrod \& Wojciech Kopczuk, The Optimal Elasticity of Taxable Income, 84 J. Pub. Econ. 91 (2002); Joel Slemrod \& Shlomo Yitzhaki, Tax Avoidance, Evasion and Administration, in 3 HANDBOоK оF PuBLIC Economics 1423 (Alan J. Auerbach \& Martin Feldstein eds., 2002); Caroline E. Weber, Toward Obtaining a Consistent Estimate of the Elasticity of Taxable Income Using Difference-inDifferences, 117 J. Pub. Econ. 90 (2014); Joel Slemrod, Methdological Issues in Measuring and Interpreting Taxable Income Elasticities, 51 NAT'L TAX J. 773 (1998). 
ETI in hand, problems like the optimal design of the tax rate structure, which previously was thought to be intractable, have become problems on which economists can realistically expect to make progress. ${ }^{6}$ Discussions of the ETI in the legal literature, however, have been relegated largely to footnotes. ${ }^{7}$ Only a handful of law-related papers engage with the ETI idea at all, usually applying it to a discrete tax policy problem. ${ }^{89}$ And no article, to our knowledge, has explored the wide range of applications of the ETI across tax law.

One possible reason for the legal academy's lack of engagement with an idea that has transformed the field of public economics is that the ETI-in its

6 The original work on the optimal design of the rate structure is due to Sir James Mirrlees. See James Mirrlees, An Exploration in the Theory of Optimum Income Taxation, 38 REv. ECON. STUD. 175 (1971). Mirrlees's approach presented daunting empirical problems. Reformulating the approach to use elasticities provided a way of making those empirical problems tractable (as well as simplifying the mathematics). Papers using the elasticities to estimate the optimal rate structure include Saez, supra note 5; Diamond \& Saez, supra note 5; Christina D. Romer \& David H. Romer, The Incentive Effects of Marginal Tax Rates: Evidence from the Interwar Era, 6 Am. Econ. J. Econ. PoL'Y 242 (2014); Piketty, Saez \& Stantcheva, supra note 5 .

${ }^{7}$ See Alex Raskolnikov, The Cost of Norms: Tax Effects of Tacit Understandings, 74 U. CHI. L. Rev. 601, 651 n.30 (2007); Chris William Sanchirico, Optimal Tax Policy and the Symmetries of Ignorance, 66 TAX L. REv. 1, 22 n.69 (2012).

${ }^{8}$ See Deborah H. Schenk, An Efficiency Approach to Reforming a Realization-Based Tax, 57 TaX L. Rev. 503 (2003); David A. Weisbach, An Economic Analysis of Anti-Tax-Avoidance Doctrines, 4 Am. L. Econ. Rev. 88 (2002). A notable exception is a 2015 article by the legal scholar David Gamage, which lays out the logic of the ETI approach and summarizes the main results of the econometric literature estimating taxable income elasticities. See David Gamage, The Case for Taxing (All of) Labor Income, Consumption, Capital Income, and Wealth, 68 TAX L. REv. 355, 390-91 (2015). That article does not, however, attempt to operationalize the ETI as a tool to resolve specific tax policy questions. 
early formulations-contained a number of simplifying assumptions that limited its ability to address to sorts of problems about which legal scholars are concerned. In particular, the early ETI-influenced work assumed a relatively simple tax system, with taxable income taxed at a single rate, and with no administrative or compliance costs. Actual tax systems, however, are enormously complex, with multiple tax bases taxed at different rates. They also impose substantial compliance costs.

We show that the ETI can be generalized and extended to better describe actual tax systems, allowing it to address an array of important problems. Our extended version of the ETI-the Behavioral Elasticity of Tax Revenuecan be used to resolve a range of questions about tax system design. ${ }^{10} \mathrm{We}$ illustrate this by showing how the BETR can be used to analyze the tax base and tax administrative and compliance choices, and how it can serve as an important input into distributional choices.

In a companion paper, we show that the BETR framework can also be used to study the interaction of the tax system and legal rules. For example, the law can choose forms of property that are more-or less-observable to the government. More observable forms property will usually be easier to tax. Similarly, the law can choose what types of payment to permit in consumer and commercial transactions. The more transparent the payment mechanism, the easier it will generally be for the government to collect a range of income, consumption, and excise taxes. Design choices in a variety of other areas-from corporate law to trust law to occupational licensing-will likewise determine the ability of individuals and firms to hide transactions from tax authorities or shift income across legal boundaries, thus affecting the tax system's functioning. The BETR allows us to analyze these choices.

10 There are a handful of places in the economics literature where approaches similar to the BETR have been suggested, though in each case differing in significant ways. We discuss these when describing the BETR below. The most relevant prior work includes Chetty, supra note 5; Hendren, supra note 5; Keen \& Slemrod, supra note 5. 
Ultimately, in this article and our companion paper, we seek to show that engagement with the ETI and its extension, the BETR, can improve positive and normative analysis of law within and beyond the tax sphere.

Our analysis in this article proceeds in four parts. Part I introduces the ETI and explains how it can be used to measure the effects of tax changes on the resources available to society. Part I then shows how the ETI can be modified and extended to more closely describe actual tax systems, giving us the BETR framework. Part II uses the BETR framework to analyze questions related to the scope of the tax base. We focus, in particular, on the taxation of mixed personal/business items, using commuting expenses as an illustrative example. Part III considers tax enforcement, including audits and reporting.

Part IV examines the relationship between the BETR and inequality. Our primary claim regarding redistribution is that policymakers interested in the redistribution of wealth should use the BETR in choosing among alternative tax and transfer policies. Whatever one thinks is the optimal amount of redistribution, policymakers should pick the most efficient mix of mechanisms for achieving that level of redistribution. The BETR framework allows policymakers to identify the most efficient mix of redistributive mechanisms, allowing either the same redistribution at a lower cost or more redistribution at the same cost. We also consider the treatment of pure transfers of money among taxpayers and across the private and public sectors.

Before proceeding further, a brief note on audience is in order. Our article is written to be understood by readers with no or negligible economics training. As noted above, we think it is important that legal scholars and policymakers understand the intuition behind the ETI and the BETR, as it potentially applies to a host of legal and policy problems upon which economists do not have sole purchase. But our article is more than a review of the economic literature geared toward laypeople. It provides not only a distillation of-but also an innovation on-the ETI concept. Our revision of the ETI captures the efficiency effects of tax changes that accounts 
for multiple tax rates, multiple tax bases, and administrative and compliance costs. No single paper in the economics literature explains how all of these moving pieces come together. We therefore anticipate that our framework will be useful not only for legal scholars applying economic insights but also for economists seeking to expand the existing ETI foundation. ${ }^{11}$

\section{The BETR}

This part explains the intuition underlying the elasticity of taxable income approach. It then considers some of the limitations of the ETI. To address these limitations, we develop our extended version of the ETI, the BETR, which more accurately describes actual tax systems, and which can more easily be used to address central questions of the design of tax systems. ${ }^{12}$ We provide a formal derivation of the BETR in a separate technical paper.

\section{A. From Elasticity of Labor Supply to Elasticity of Taxable Income}

The traditional method of calculating the resource effects of income taxation emerged from an influential 1964 article by the University of Chicago economist Arnold C. Harberger. ${ }^{13}$ The basic idea behind Harberger's approach was to think of a tax on labor income as a uniform tax on all market

${ }^{11}$ In a companion paper, we consider a range of non-tax legal applications of the ETI that economists have not explored or even recognized-in part because they pertain to questions that are at the core of legal scholarship but that are tangential to public economics. There, we show how the ETI approach can enrich the study of non-tax legal questions and potentially improve the design of laws.

12 In prior work, we called the BETR the "Marginal Revenue Rule." David A Weisbach, Daniel J. Hemel \& Jennifer Nou, The Marginal Revenue Rule in Cost-Benefit Analysis, 160 TAX NoTES 1507 (2018). We have changed the acronym to better capture the measure.

${ }^{13}$ Arnold C Harberger, Taxation, Resource Allocation, and Welfare, in THE Role OF DiRECT AND INDIRECt TAXES IN the FEDERAL RESERvE System 25 (NBER ed., 1964). 
goods. Individuals earn labor income, pay tax on those earnings, and then purchase goods in the market. Because all market goods are purchased with after-tax income, ${ }^{14}$ a tax on labor income is equivalent to a tax on all market goods at a uniform rate.

A tax on labor income will cause individuals to shift toward non-market goods because non-market goods become relatively less expensive. Nonmarket items include everything that is not paid work, including napping in a hammock, raising children, washing dishes, and taking out the trash. Economists somewhat confusingly call all non-market items "leisure," even if many of these activities may not fit the colloquial sense of that term. Economists call market work "labor," even though many non-market items may also seem like labor and many people enjoy their market work. Although the terms "market" and "non-market" are more accurate, we will use the standard terms rather than inventing new terminology. The shift due to taxes-from taxable, market activities (labor) to non-market activities (leisure)—is called the labor/leisure distortion (or using more meaningful terms one last time, the market/non-market distortion).

To understand the costs of the labor/leisure distortion, consider an individual who earns $\$ 10$ an hour from labor and is subject to a 30 percent tax rate. The individual will allocate her time between labor and leisure such that she is indifferent between an additional hour of labor and an additional hour of leisure. Put differently, she is indifferent between the bundle of goods that she could purchase with $\$ 7$ of after-tax income from the extra hour of work and the value of an additional hour of time spent not engaging in market work. If that is not the case and, for example, the individual values an

${ }^{14}$ Individuals earn income from labor and from capital (saving). Because a tax on only labor income (i.e., a tax that excludes capital income) will approximate a consumption tax, we can set aside capital income for present purposes. For a discussion, see Joseph Bankman \& David A. Weisbach, The Superiority of an Ideal Consumption Tax over an Ideal Income Tax, 58 STAN. L. REv. 1413 (2006). 
additional hour of leisure time at $\$ 6$, she will be better off working more until the value of an additional hour of leisure rises to $\$ 7 . .^{15}$ Symmetrically, if the individual values an additional hour of leisure time at $\$ 8$, she will be better off working less until the value of an additional hour of leisure falls to $\$ 7$. We can therefore use the after-tax wage rate to estimate the value of an additional hour of leisure to an individual.

A feature of Harberger's approach (and as we will see, the ETI) is that it includes the value of all resources, not just taxable income or money income. The individual in our example values an additional hour of work and an additional hour of free time equally, at $\$ 7$. Therefore, Harberger's measure captures the value of both. That is, although it uses money income as a metric, it measures the value of other things as well.

The insight underlying Harberger's approach is that the cost of a marginal change in the tax rate on labor income can be calculated based on the change in labor supply induced by the tax change. To illustrate: Imagine that the tax rate rises from 30 percent to infinitesimally more than 30 percent, causing an individual to reallocate one hour from labor to leisure. The individual is not materially worse off than before, because she was previously indifferent between an additional hour of labor and an additional hour of leisure. Society, however, is $\$ 3$ worse off, because the government raises $\$ 3$ less of revenue and can purchase $\$ 3$ less of public goods. Society has $\$ 3$ less in total resources, a value that economists have termed "deadweight loss." This is a cost of taxation in the sense that this value disappears. And for reasons just noted, the $\$ 3$ does not just disappear from taxable income, money income, GDP, or some other narrow measure of value.

${ }^{15}$ As is standard, we assume that the individual's marginal utility of leisure is diminishing - the more leisure time she has, the less value she assigns to an additional leisure hour. 
It disappears completely even taking into account the benefit of the free time our individual gains.

The key input into calculating the deadweight loss of income taxation, according to Harberger's approach, is the price elasticity of labor supply. ${ }^{16}$ The price elasticity of labor supply can be stated as the percentage change in the number of hours worked that results from a 1 percent change in the after-tax wage rate. The deadweight loss from an income tax turns out to be calculable on the basis of the price elasticity of labor supply, the tax rate, and the total amount of labor income. ${ }^{17}$

An important assumption underlying Harberger's approach is that labor supply is the only welfare-relevant dimension along which individuals adjust

${ }^{16}$ Harberger, supra note 12 , at $47-48$.

${ }^{17}$ Harberger expresses the deadweight loss of a labor income tax as $1 / 2 e r^{2} w l$, where $e$ represents the price elasticity of labor supply, $r$ is the income tax rate, and $w L$ represents total earnings from labor gross of income tax. Id. at 45-46.

In some thought experiments, economists compare the resources available under a labor income tax to those available under what they call a "lump sum" tax. In our simple, one-person case, a lump sum tax is simply a fixed tax that the person has to pay no matter what. When there is more than one person, a lump sum tax might be an equal per capita tax or perhaps an individualized tax based on observable attributes. In the thought experiment comparing a labor income tax to a lump sum tax, the person's income does not change because the tax is paid either way. Therefore, any effects on welfare due to the change in income are netted out, leaving only costs due to what is known as the substitution effect. To the extent this is the correct thought experiment, the relevant parameter is the price elasticity of labor supply holding utility fixed, a value called the "compensated elasticity." It is not clear, however, that this is the right thought experiment instead of the one in the text, which does not hold income fixed. Regardless of which thought experiment is correct, however, empirical studies show that income effects are likely small, which means that the difference may not be meaningful. See Gruber \& Saez, supra note 5. Uncompensated values are both simpler to understand and easier to measure. As a result, we refer to uncompensated values in the text. 
their behavior in response to a labor income tax. Changes in labor supply, however, are far from the only behavioral responses to changes in tax rates. A higher tax rate may induce workers to take more of their compensation in nontaxable form (e.g., untaxed fringe benefits), or to shift toward work in the informal economy (i.e., the black market), or to invest more in tax shelters, or to engage in more outright evasion. All of these changes have welfare consequences that a singular focus on labor supply fails to capture.

Martin Feldstein, in a pair of papers in the 1990s, proposed the ETI as a way of addressing these concerns. Feldstein's advance was to recognize that even though taxation leads individuals to adjust their behavior in a wide variety of ways, the efficiency effects of all of these adjustments can be summarized by a single "sufficient" statistic: the elasticity of taxable income. That statistic, moreover, can be estimated even when the underlying behavioral adjustments cannot be observed.

What makes this possible is the assumption that individuals optimize not only on the labor/leisure margin, but on all other margins as well. Thus, a small tax change that causes an individual to adjust any of her behaviors has no first-order effect on the individual's well-being but changes the total amount of resources available to society by the change in taxable income multiplied by the tax rate.

To illustrate: Imagine again that the tax rate is 30 percent and that an individual has the option to receive some of her income in nontaxable formfor example, as a contribution to her health insurance plan. That is, the individual can choose to receive $\$ 10$ less in taxable wages and have her employer contribute $\$ 10$ more to her health insurance, which will then be excluded from taxation. The individual will shift dollars from her taxable wages to her health insurance plan until she is indifferent between (a) receiving an additional $\$ 10$ in taxable wages and paying $\$ 3$ in tax, thus leaving \$7 in after-tax wages, and (b) having her employer contribute an additional $\$ 10$ to her health insurance (which she values at $\$ 7$ ). 
Now imagine again that the tax rate rises from 30 percent to slightly more than 30 percent, causing the individual to reallocate an additional $\$ 10$ from taxable wages to employer-paid health insurance. The individual, once more, is not materially worse off than before, because she was previously indifferent between an additional $\$ 10$ of taxable wages and an additional $\$ 10$ of health insurance. But society is worse off by $\$ 3$ - the change in taxable income times the tax rate-because the government now collects $\$ 3$ less in taxes and can purchase $\$ 3$ less of public goods.

The effects of the tax law change, Feldstein argued, can therefore be measured by how much taxable income changes when we change tax rates. He expressed this as an elasticity: the elasticity of taxable income is the percent change in reported taxable income for a percent change in the tax rate. If, in our example, taxable income went down by 1 percent when the tax rate went up by 1 percent, the ETI would be -1 . The higher (in absolute value) the ETI, the greater the loss in resources due to taxation.

The ETI applies broadly. It works just as well when taxpayers' choices are discrete (e.g., whether to enter or exit the labor force) as when their choices are continuous (e.g., how many hours to work), so long as the taxpayer was previously in equipoise between the two options. Economists use the term "extensive margin" to refer to the choice of whether to work at all, and the term "intensive margin" to refer to the choice of how many hours to work. Empirical research on the price elasticity of labor supply has long sought to separately estimate these two quantities. ${ }^{18}$ The ETI approach eliminates the need to draw a distinction between the two.

To illustrate: Imagine that an individual is indifferent between (a) remaining in the workforce and earning a $\$ 100,000$ salary and (b) retiring so that she has more time to fish and play golf. Assume, as at the outset, that the

${ }^{18}$ See James J. Heckman, What Has Been Learned About Labor Supply in the Past Twenty Years?, 83 Am. Econ. Rev. 116 (1993). 
tax rate is a flat 30 percent. A small increase in the tax rate that causes the individual to shift from working to retiring will have no material impact on the individual's utility (after all, she was indifferent between the two options) but will reduce the total resources available to society by the change in taxable income times the tax rate (here, $\$ 100,000 \times 30 \%$, or $\$ 30,000$ ).

The ETI approach also accounts for the influence of taxation on career choices in ways that Harberger's approach does not. To illustrate again: Imagine that an individual is choosing between a job as a software developer that pays $\$ 100,000$ per year and as an interior designer that pays $\$ 50,000$. Suppose that the interior designer job, while less remunerative, is more enjoyable. Both involve the same number of hours. Assume that the tax rate is 30 percent.

Imagine that the individual values the added enjoyment of working as an interior designer rather than a software developer at $\$ 35,000$; thus, he is indifferent between working as a software developer (after-tax income of $\$ 70,000$ ) and working as an interior designer (after-tax income of $\$ 35,000$ ). If the top tax rate goes up from 30 percent to 30.01 percent, the individual will shift from software development to interior design. He will not be materially worse off than before, but he will have $\$ 50,000$ less in taxable income. As a result, total resources available to society have declined by the tax on this income, $30 \% \times \$ 50,000$, or $\$ 15,000$. The ETI approach captures this change because it measures his change in taxable income (from $\$ 100,000$ to $\$ 50,000$ ), which is then multiplied by the tax rate.

The ETI applies as well when the relevant behavioral adjustment involves a change in tax reporting. Assuming again a tax rate of 30 percent, an individual will report income until she is indifferent between reporting an additional $\$ 1$ (thus leaving her with $\$ 0.70$ after taxes) and not reporting an additional $\$ 1$. To frame the same point in mirror image, the individual will evade tax until she is indifferent between evading taxes on an additional \$1 and paying another $\$ 0.30$ in taxes. The cost of evasion may be the real resource cost (e.g., opening a Swiss bank account to shelter income), or it 
may be the disutility from knowing that she could go to jail, or it may be the "moral disutility" from knowing that she is not complying with her legal obligations. ${ }^{19}$ Whichever it is (and it could be all of the above), a change that causes an individual to report an additional \$1 of income-such as an increase in audits or penalties - does not leave her materially worse off than before, because the tax savings are approximately equal to the evasion costs. It does, however, increase total resources by the change in taxable income times the tax rate, because the government now has that much more for public goods.

Before the development of the ETI, analysts understood that shifts along non-labor margins were important. To understand the effects of these shifts, however, they tried to estimate the costs along each margin and then aggregate. The ETI vastly simplifies the analysis because we only need to estimate one parameter, how taxable income changes, to understand the effects along all these margins simultaneously. Because of its generality and its simplicity, the ETI spawned a large economics literature. ${ }^{20}$ Primarily the ETI was used to derive more accurate estimates of the deadweight loss of tax rate changes. ${ }^{21}$ Our goal is to use the ETI to examine the design of the tax system. To do this, we need to expand the ETI to better reflect important elements of the tax system that, in its standard form, the ETI leaves out. The remainder of this part develops that framework.

${ }^{19}$ On the role of "moral disutility" in the economic analysis of law, see generally Bruno Deffains \& Claude Fluet, Legal Liability When Individuals Have Moral Concerns, 29 J. L. Econ. \& ORG. 930 (2013).

${ }^{20}$ See sources cited supra note 5.

${ }^{21}$ Key exceptions were the use of the ETI to examine the optimal scope of the tax base and to examine the optimal level of tax enforcement. See Slemrod \& Kopczuk, supra note 5 (tax base); Keen \& Slemrod, supra note 5 (tax enforcement). 


\section{B. Extending the Elasticity of Taxable Income: the BETR}

The ETI, as developed in the economics literature, suffers from two important limitations. The first is that the ETI assumes that all taxable income is taxed at a single rate. (It allows income to be outside of the tax base-such as fringe benefits and black-market income-but assumes that any such income is not taxed at all.) Most tax systems, however, apply different rates to different types of income and to different taxpayers. For example, the United States has increasing marginal rates for individuals, and its taxes corporate income at a different rate than it taxes individual income. When different types of income or taxpayers are taxed at different rates, the ETI will often fail to correctly measure the change in social resources due to a tax change.

Second, the ETI does not explicitly incorporate the costs of tax administration and compliance and cannot easily capture these costs without modification. These costs, however, have first-order welfare implications. They are large-in the range of 1 percent of GDP according to two recent estimates ${ }^{22}$-and central to tax system design. We show here how the ETI can be modified to account for both these problems.

\section{Multiple Tax Bases and Rates}

The ETI is a measure of how taxable income changes when we make a change to the tax system. If different income is taxed at different rates, however, a focus on the change in taxable income will not correctly capture

22 See Rosemary Marcuss et al., Income Taxes and Compliance Costs: How Are They Related?, 66 NAT'L TAX J. 833 (2013) (estimating in 2013 that income tax-related compliance costs in the United States exceeded $\$ 150$ billion, or approximately $0.9 \%$ of gross domestic product that year); Youssef Benzarti, How Taxing Is Tax Filing? Using Revealed Preferences to Estimate Compliance Costs (Nat'l Bureau of Econ. Research, Working Paper No. 23903, 2017), https://ssrn.com/abstract=3049727 (estimating that federal income tax filing costs and related compliance costs are approximately $1.2 \%$ of GDP). 
how taxes affect total resources. To translate the ETI into a measure of the change in real resources, we need to multiply the ETI by the applicable tax rate.

To see why, consider a tax system that has increasing marginal rates. To be concrete, assume that low-income taxpayers are taxed at a 20 percent rate, and above some threshold, the marginal rate goes up to 40 percent. Suppose we make a small change to the tax laws that causes low-income taxpayers, subject to the 20 percent rate, to earn $\$ 1$ more and high-income taxpayers, subject to the 40 percent rate, to earn $\$ 1$ less. For simplicity (although this need not be the case for the analysis), assume that their combined taxable income is unchanged: low-income taxpayers have one more dollar of income and high-income taxpayers one less, netting to no change in overall taxable income. Looking at taxable income, therefore, we would conclude that the change in the law had no effect on available resources. ${ }^{23}$ In fact, the change in the law reduces total resources by $\$ 0.20$. Using the same logic as above, both the low-income and high-income taxpayers are indifferent to the change because they were indifferent to earning a bit more or a bit less prior to the change. ${ }^{24}$ There is, however, $\$ 0.20$

${ }^{23}$ In the text, we suggest that the ETI measure will produce the wrong result because overall taxable income has not changed, which means it fails to identify the change total social resources. An alternative characterization of the problem is that the ETI is undefined when there is more than one tax rate. The ETI is conventionally derived assuming there is a tax rate that affects behavior, and it is the elasticity of taxable income with respect to this tax rate (or often, the net of tax rate or 1-t). For example, the derivation of ETI in a well-known paper by Raj Chetty assumes there is single tax rate, and the elasticity is defined by reference to this rate. See Chetty, supra note 5. If there is more than one rate, it is not clear which tax rate is to be used in the elasticity calculation.

24 The notion that taxpayers are no better or worse off when they earn $\$ 1$ more or $\$ 1$ less will strike some readers as counterintuitive. Later in this section, we discuss the wide range of circumstances in which taxpayers are better (or worse) off with $\$ 1$ more (or less). The indifference result applies where the taxpayer has optimized the allocation of her time between labor and leisure and then moves marginally in one direction or the other. 
less in tax revenue. The low-income taxpayers pay $\$ 0.20$ more in tax and the high-income taxpayers pay $\$ 0.40$ less, so tax revenues go down by a net of $\$ 0.20$. This translates to $\$ 0.20$ less in total resources because there is $\$ 0.20$ less tax revenue while neither group of taxpayers is otherwise better or worse off.

The same logic applies to corporations and individuals. We can use the same example: under current law, corporations are low-taxed taxpayers with a roughly 20 percent rate and high-income individuals, the high taxed ones, with a roughly 40 percent rate. ${ }^{25}$ Lowering individual tax rates, for example, may increase income reported on individual returns and simultaneously reduce income reported on corporate returns because the relative advantage of earning income in each place has changed. ${ }^{26}$ The ETI will not correctly measure the effects of the tax change in this case, for the same reasons as above.

The problem arises in a number of other contexts as well. For example, when a tax system applies a higher rate to ordinary income than to capital gains, a shift from ordinary income to capital gains will not affect total taxable income but will affect tax collections. Suppose that the ordinary income rate is 40 percent and the capital gains rate is 20 percent, and that a taxpayer-at cost of $\$ 20$ - can reorganize her affairs so as to transform $\$ 100$

25 The corporate income tax rate starting in 2018 is $21 \%$. I.R.C. $\S 11(\mathrm{~b})$. The highest individual income tax bracket is 37\%, see id. §1(j)(2), but the Affordable Care Act imposes an additional surtax on high earners that raises the top marginal income tax rate to $40.8 \%$. See id. $\S \S 1401,1411$.

${ }^{26}$ There is substantial evidence that large amounts of income are shifted between the corporate and individual bases. See Roger Gordon \& Joel Slemrod, Are "Real" Responses to Taxes Simply Income Shifting Between Corporate and Personal Tax Bases, in DoEs ATLAS Shrug?: The Economic Consequences of TAXing The Rich (Joel Slemrod ed., 2000); Matthew Smith et al., Capitalists in the Twenty-First Century (Nat'l Bureau of Econ. Research, Working Paper No. 25442, 2019), https://ssrn.com/abstract=3315276. 
of ordinary income into capital gains. The taxpayer is indifferent between the two alternatives. If she earns $\$ 100$ as ordinary income, she will pay $\$ 40$ in taxes. If she earns $\$ 100$ as capital gains, she will pay $\$ 20$ in taxes and $\$ 20$ in other expenses. But society bears a real resource cost when the taxpayer shifts across bases: when she earns $\$ 100$ of capital gains instead of ordinary income, the government has $\$ 20$ less to spend on public goods.

Early versions of the ETI looked only at individual taxable income, not accounting for the fact that some of the change in income at the individual level reflected moves to or from the corporate base. This approach produces clearly wrong results because it does not include the change in corporate taxable income. After the problems with this approach were identified, scholars tried to patch up the ETI by adding a term that would capture the elasticity of income shifting from the individual to corporate bases. ${ }^{27}$ As noted above, however, shifting between the individual and corporate bases is just one among a number of possible dimensions along which income shifting can occur. Shifts can occur across individuals in different brackets, across types of income taxed at different rates, from the individual income base to the estate and gift base, and so on. Other countries also have value added taxes and may see shifting to or from that base. The ETI will not properly measure the effects of taxes in any of these cases.

The fix to the ETI requires two partially offsetting changes. As illustrated in the discussion above, the change in resources due to a change in policy depends on the change in tax revenue, not the change in taxable income. The ETI, as formulated, focuses on taxable income. When there is more than one tax rate, however, looking at changes in taxable income and looking at changes in tax revenues are not the same. In the first example in this subsection involving low-rate and high-rate taxpayers, the low-rate

27 See, e.g., Chetty, supra note 5; Saez, supra note 5; Slemrod, supra note 5; Emmanuel Saez, Joel Slemrod \& Seth H. Giertz, The Elasticity of Taxable Income with Respect to Marginal Tax Rates: A Critical Review, 50 J. Econ. LiT. 3 (2012). 
taxpayers paid $\$ 0.20$ more in tax while the high-rate taxpayers paid $\$ 0.40$ less. Resources declined by the net change in tax payments, not by the change in taxable income. When there is more than one tax rate, we have to look at tax revenues. Therefore, the first change to is to focus on tax revenue, not on taxable income. That is, we need to use the elasticity of tax revenue, or ETR.

The second change is that once we switch to changes to tax revenue, we have to adjust for changes in revenue that are not due to behavioral changes. In particular, by looking at changes to taxable income, the ETI implicitly captures only changes in behavior. If we increase the tax rate, for example, individuals may work less, and measuring changes to taxable income measures how much less they work. If we instead look at the change in tax revenue from an increase in rates, however, we also capture what economists call "mechanical" effects, which are changes in tax revenue due to rate changes when behavior remains constant. Mechanical effects are transfers between taxpayers and the government, and unlike tax payments due to behavioral effects, individuals are not indifferent to mechanical effects. That is, an increase in tax payments due to a mechanical effect makes the taxpayer worse off and the government better off by an offsetting amount, and vice versa for a reduction. Therefore, to capture the resource change for a change in policy when there are multiple tax rates, we need to subtract mechanical effects.

To illustrate, consider an individual with $\$ 100$ of taxable income, currently taxed at 30 percent. Suppose we lower her tax rate by 1 percent of 30 percent (to 29.7 percent) and she responds by increasing her taxable income by 1 percent of $\$ 100$ (to $\$ 101$ ). The ETI is - 1 : a 1 percent reduction in the tax rate results in a 1 percent increase in taxable income. The change in tax revenue, however, is almost $\$ 0$ : she has a higher taxable income taxed at a lower rate. Tax revenues after the change in rates are $\$ 29.997$ (i.e., $29.7 \% \mathrm{x}$ $\$ 101$ ), which is almost identical to the $\$ 30$ in tax revenues before rate change (with the net change being only -\$0.003). A naïve focus on tax revenues would lead us to conclude that the change had almost no effect on social resources even though the elasticity of taxable income is fairly high. 
In fact, the change in resources due to the tax change is (positive) $\$ 0.297$, not $-\$ 0.003$. To see why, break down the taxpayer's behavior into two components. The first is the additional $\$ 0.297$ she pays because she works an extra hour. Under the arguments made above, she is indifferent to this additional payment but the government gains $\$ 0.297$. This amount reflects more social resources. The second component is the $\$ 0.30$ less tax she pays on her original $\$ 100$ of earnings. This is a pure gain to her. Unlike her change in tax payments due to behavioral changes (which were due to an hour more work and an hour less leisure), she does not have to sacrifice anything to get it. She simply has that much more money. It is also, however, a loss to government, which has that much less revenue. The $\$ 0.30$ change in tax revenue due to the mechanical effects of the tax is a pure transfer between the taxpayer and the government. She is better off by that $\$ 0.30$ and the government is worse off by $\$ 0.30$.

The same effect arises when there are a large number of taxpayers affected by rule change and only some alter their behavior. For example, we considered above the how the ETI can measure the extensive margin for labor choices, such as the choice whether to enter into the workforce or when to retire (as opposed to the intensive margin, which is how many hours to work). These changes are binary in the sense that one enters the workforce or one does not. A change in the law that causes someone right on the margin between working and not working to switch will also likely affect many people who are not on the margin and do not change their choice. They either stay in or stay out of the workforce. The effects of the tax change on these individuals is mechanical. Any increase in tax payments makes them strictly worse off and the government better off, and vice versa for decreases in tax payments.

Therefore, when calculating the change in resources due to the tax change, we need to net out mechanical changes. We should focus only on tax 
revenue changes due to behavioral effects. We want the "behavioral elasticity of tax revenue" or the BETR. ${ }^{28}$

Note that netting out transfers involves a judgment about the value of money in the hands of taxpayers and the government. Netting the $\$ 0.30$ in the example treats money held by taxpayers and money held by the government as worth the same. This will not always be true: sometimes the government may have projects that are more valuable than the projects taxpayers would pursue with the money, and sometimes the reverse will be true.

We will take up the treatment of transfers in Part IV. ${ }^{29}$ Note, however, that the ETI implicitly and automatically nets mechanical effects while the BETR allows flexibility in how they are treated. If one believes that money is systematically worth more, or worth less, in the hands of the government than in the pockets of taxpayers, the BETR can be modified by multiplying transfers by a factor representing the difference in value. For example, if we believe that the value of a dollar held by the government is 25 percent greater than the value of the same dollar held by taxpayers, we can multiply the transfer component by 0.25 . If we think it is 25 percent less than the

${ }^{28}$ For a similar suggestion, see Hendren, supra note 5, at 62 (equation 9). The idea of measuring the welfare effects of tax changes this way is not new. Economists have expressed the behavioral revenue effects as the difference between the total revenue effects from a change and the mechanical effects. See Chetty, supra note 5, at 44 (equation 33). Chetty, however, argued that this approach is equivalent to measuring the change in taxable income (and we believe this view is standard). We argue in the text that it is not when income is subject to more than one tax rate. Slemrod hints at our argument in passing. Slemrod, supra note 5 , at 778 .

${ }^{29}$ The discussion in the text focused on transfers between taxpayers and the government. In Part IV, we also discuss transfers between taxpayers, such as charitable donations. Both the ETI and the BETR need to be adjusted to take transfers between taxpayers into account. 
value of the same dollar in a taxpayer's hands, we can multiply the transfer component by -0.25 . The behavioral component, by contrast, is unambiguously a change in resources. The ETI does not allow this flexibility because it implicitly nets transfers unlike the BETR, which nets them explicitly.

Our view is that transfers should be valued at 1 (i.e., not multiplied by a factor, as discussed above), but they should also be separately stated for any policy change being evaluated, so that those with differing views can make appropriate adjustments. The BETR would, under this approach, reflect only what are unambiguously changes to resources. We defer our reasons for this approach, however, to Part IV.

\section{Tax Administration and Compliance}

The other problem with the ETI is that it does not capture the costs of tax enforcement. The costs of tax enforcement include amounts spent by the government to administer the tax laws (tax administration) and amounts spent by taxpayers to comply with those laws (tax compliance).

Administrative costs in the United States are relatively modest-the budget of the Internal Revenue Service is about $\$ 12$ billion per year-but compliance costs are estimated to be more than ten times that ${ }^{30}$ The failure to include administrative and compliance costs in the ETI leads in some cases to the formula generating results that are clearly incorrect.

\section{a. Administrative Costs}

To understand how administrative costs affect the ETI, return to our example of tax reporting in Section I.A. There, we imagined an individual who is subject to a 30 percent rate and who is indifferent between reporting an additional $\$ 1$ (thus leaving her with $\$ 0.70$ after taxes) and not reporting an

\footnotetext{
${ }^{30}$ See Marcuss et al., supra note 22; Benzarti, supra note 22.
} 
additional \$1 but incurring costs related to non-reporting, such as evasion costs. We considered a change-say, increased audits or penalties-that causes her to report an additional $\$ 1$ of income. The change does not leave her materially better (or worse) off than before, because the additional tax payment is approximately equal to her reduced evasion costs. The change, however, increases tax revenues by $\$ 0.30$, the change in reported income times the tax rate.

The piece we left out of this story was the cost to the government from the change in tax administration (e.g., the cost of conducting additional audits or imposing additional penalties). To add this in, suppose that when the government increases its audit rate or otherwise changes tax administration policies, it has to spend $\$ 0.20$ more. What is the change in resources in this case? The taxpayer is indifferent to the change but there is $\$ 0.30$ more tax revenue, as discussed above. Yet there is also a cost of $\$ 0.20$ in enforcement expenses. The net increase in resources is only $\$ 0.10$, not $\$ 0.30$. We have to net out any change in the costs of tax administration from change in tax revenue to determine the increase or decrease in available resources due to a shift in policy.

\section{b. Compliance Costs}

A similar, though somewhat more complex, analysis applies for compliance costs borne by the private sector. Start with a relatively simple case in which the government requires all taxpayers to keep additional records or submit additional information with their tax returns, and this change-because it makes income more easily observable or deductions more easily verifiable - causes an individual to report an additional $\$ 1$ of income. Assume again that the taxpayer was previously indifferent between reporting the additional income (and paying $\$ 0.30$ in taxes) or bearing $\$ 0.30$ in evasion costs. Assume also that the tax rate is 30 percent and that the additional recordkeeping or tax filing cost is $\$ 0.20$. 
The analysis is essentially identical to the administrative-cost case, except with the $\$ 0.20$ cost borne by the taxpayer rather than the state. The government again has $\$ 0.30$ more in tax revenue, and there is also a social cost of $\$ 0.20$. The net increase in resources is $\$ 0.10$, not $\$ 0.30$. Here again, we must net out the change in the costs of tax compliance from the change in tax revenue in order to arrive at an accurate calculation of the change in resources.

If the taxpayer can deduct compliance costs (e.g., the compliance costs are ordinary and necessary expenses of the taxpayer's trade or business), the analysis remains largely the same, but with one modification. Now, the extra $\$ 0.20$ in compliance costs means that the taxpayer will be able to claim an additional deduction of $\$ 0.06$ (i.e., $30 \% \times \$ 0.20$ ). Thus, the imposition of the recordkeeping or filing burden on the taxpayer leaves her $\$ 0.14$ worse off, not $\$ 0.20$ worse off. The government, meanwhile, loses $\$ 0.06$ in revenue as a result of the deduction. The BETR should neither double-count nor undercount these costs. Since the BETR already captures the change in government revenue as a result of the additional deduction $(-\$ 0.06)$, only the taxpayer's after-tax compliance costs should be subtracted from the calculation of the resource change.

Some compliance costs, however, are discretionary in the sense that they are driven by behavioral choices. For example, the costs of engaging in a particular activity such as investing or starting a business may include tax compliance costs. Taxpayers, when making decisions about whether or how much to engage in the activity, will take the resulting tax compliance costs into account. They are "behavioral" compliance costs as distinct from "mechanical" compliance costs that taxpayers will bear regardless of how they alter their other behavior. Behavioral compliance costs should not be subtracted from net revenue.

To illustrate why, imagine again a taxpayer subject to a 30 percent tax rate who is deciding whether to report an additional $\$ 1$ of income, but this time imagine that the cost of reporting includes not only the $\$ 0.30$ tax cost 
but also an additional $\$ 0.10$ cost that the taxpayer will bear only if she reports this item of income (e.g., the cost of attaching to her return another Form 1099-MISC, which is the form used to report miscellaneous items of income). Assume that the taxpayer is initially indifferent between reporting and not reporting (i.e., the cost to her of not reporting-the evasion cost-is equal to the sum of the $\$ 0.30$ tax cost and the $\$ 0.10$ compliance cost that she will bear if she does report).

Now consider a policy change (e.g., more frequent audits or higher penalties) that pushes the individual over the edge and causes her to report the additional income. The taxpayer is essentially no worse off than before (she bears $\$ 0.40$ in additional tax and compliance costs but $\$ 0.40$ less in evasion costs). Meanwhile, total resources available to society have increased by $\$ 0.30$ (the change in tax revenue). Here, subtracting compliance costs from net tax revenue would yield the wrong answer: it would suggest that total resources had increased by $\$ 0.20$ when in fact they have risen by $\$ 0.30$. In this case, calculating the change in resources requires that we not subtract compliance costs. Intuitively, this is because the reduction in evasion costs fully offsets (from the taxpayer's perspective) both the increase in tax costs and the increase in compliance costs. All that is left is the change in net tax revenue, which represents a change in total resources.

Thus in calculating the change in available resources, after-tax mechanical compliance costs (but not behavioral compliance costs) should be subtracted from net tax revenue. That is, we are focused only on after-tax costs borne by the private sector (i.e., compliance costs minus the value of any deduction allowed for those costs), and we are focused only on 


\section{mechanical compliance costs (i.e., compliance costs that the taxpayer is not indifferent to bearing). ${ }^{31}$}

${ }^{31}$ For prior work on adjusting the ETI to account for tax enforcement, see Keen \& Slemrod, supra note 5. Our approach differs from Keen and Slemrod because we treat administrative costs borne by the government and compliance costs borne by the private sector in the same way. That is, we assume that if we increase enforcement costs by $\$ 0.20$, there are $\$ 0.20$ fewer resources available regardless of whether the money is held by the government or by taxpayers.

Keen and Slemrod, and as far as we know all other treatments of the issue in economics, weight administrative expenses by the cost of raising the necessary tax revenue. See id.; Joel Slemrod \& Shlomo Yitzhaki, The Optimal Size of a Tax Collection Agency, 89 ScAND. J. Econ. 183 (1987). The idea behind this approach is that we must raise taxes to pay for tax administration costs, and therefore, need to account for the distortions due to these higher taxes. We do not need to raise taxes to pay for compliance costs and, therefore, we do not need to account for tax distortions. As a result, all else equal, under Keen and Slemrod's approach, we should prefer imposing compliance costs to administrative costs.

There are two problems with this approach. First, there is no reason to think that compliance costs will-as a general matter-distort choices any less than other taxes will. Compliance costs are just as much exactions as taxes are. Imagine that enforcement costs go up linearly with income. For example, suppose that the tax rate is $30 \%$ and enforcement costs are $3 \%$ of income. If we impose these costs on taxpayers as compliance costs, then taxpayers will presumably act as if they face a $33 \%$ tax rate, but the government only gets tax payments of $30 \%$ of reported income. We could equivalently increase the nominal rate to $33 \%$, eliminate compliance costs, but use the additional tax revenue to enforce the tax. Taxpayer behavior would be the same and net government revenues are the same (meaning that the government can purchase the same public goods as before). There is no efficiency advantage in this case of imposing compliance costs rather than imposing additional income taxes to finance administrative costs.

Second, insofar as compliance costs are orthogonal to a taxpayer's income (i.e., they do not depend on how much money a taxpayer makes), then they operate much like lump sum taxes. As we discuss in Part IV, the government also has the option to finance administrative costs through lump sum taxes (and, for good reason, chooses not to). There is no reason to 


\section{Summary}

We are now in a position to state the full BETR: the change in social resources due to a small change in tax policy is, approximately, the change in tax revenue due to behavioral changes minus any increase in administrative costs and any increase in after-tax mechanical compliance costs. If transfers between taxpayers and the government are treated as changing social resources, the BETR includes the net value of this change. The BETR is based on the ETI but is different than the ETI in three ways: (1) it shifts the focus from the change in taxable income to the change in tax revenue due to behavioral changes, which allows it to accommodate multiple tax rates and bases, (2) it includes an adjustment for changes to the costs of tax enforcement, and (3) if appropriate, the BETR can include the net value of transfers between taxpayers and the government-the ETI implicitly treats the value of such transfers as zero. These differences allow the BETR to match actual tax systems more closely than the ETI and, therefore, to address a wider range of problems.

The BETR informs the design of tax systems in two related, but distinct, ways. First, it can be used to identify likely places for reforms by identifying margins where the gains are large. For example, as we discuss below, the BETR can be used to measure the cost of an exclusion from the tax base, such as, say, the exclusion of a fringe benefit. If eliminating or reducing the extent of the exclusion leads to a large increase in resources, then that area of the law is a good target for reform. Or, if the exclusion is desired for other reasons, the BETR can tell us what the cost is of retaining the exclusion.

Second, the BETR can be used to find optimal tax systems. Under an optimal tax system, subject to the distributional constraints we discuss in 
Part IV, the BETR should be equal to zero for all choices. ${ }^{32}$ If not, we can increase total resources by changing policies. For example, suppose for a given margin, such as an enforcement choice or a tax rate, the BETR is negative. We can reduce the intensity along that margin (e.g., reduce enforcement or lower the rate) and increase total resources. Conversely, if the BETR is positive on a given margin, we can increase the intensity along that margin, increasing total resources. When the BETR is zero along a given margin, there are no gains or losses in total resources from shifting the intensity of that margin.

Note that at the optimum, we must set the BETR to zero along all margins simultaneously. Choices along each margin affect the BETR for other margins. For example, the effects of a change in the tax rate depend on the audit rate and vice versa. If the audit rate is low, an increase in the tax rate might not produce much revenue because people would simply report less. If the audit rate is high, the increase in tax revenue from a tax rate increase might be much larger. Similarly, the effects of changing the audit rate depend on the tax rate. The two policies, the tax rate and the audit rate, must be set simultaneously. The same is true for all policy choices.

Below, we explore the use of the BETR both to find plausible areas for reform and to determine optimal policies.

\section{The Tax Base}

We illustrate the value of the BETR by addressing the central problem of tax scholarship: what should be taxed? In the next part we turn to tax enforcement. While we treat these subjects separately, policies related to the tax base and to tax enforcement-as just noted-are and ought to be set

32 Mathematically the BETR is just the derivative of utility with respect to a policy choice. Maximizing requires setting the derivative to zero for all policy choices simultaneously. 
simultaneously. What we choose to tax is in large part a function of enforcement costs. For example, one reason why we do not tax household production-even though it is often as important as market production ${ }^{33}$-is that we can observe the returns to market production (wages, benefits, and so forth) more easily than we can observe the returns to household production (a clean home, well-raised children, and so forth). ${ }^{34}$ The challenge of observing household production would make an income or consumption tax that included household production within its base extraordinarily difficult to enforce. Similarly, one reason why developing countries tend to rely more on tariffs and excise taxes-and less on personal income taxes-is the difficulty of enforcing a personal income tax in an economy with a large informal sector. ${ }^{35}$ As we discuss in our companion paper, this interdependence extends to legal institutions as well. The optimal set of legal rules in a polity will depend on its tax system, and the optimal design of its tax system will depend on the polity's legal institutions.

33 See Henry C. Simons, Personal Income Taxation 53 (1938); Victor Thuronyi, The Concept of Income, 46 TAX L. REv. 45, 60-61 (1990). For an overview and critique of arguments against the taxation of household production, see generally Nancy C. Staudt, Taxing Housework, 84 GEo. L.J. 1571 (1996).

${ }^{34}$ Many of the most important academic works in tax law implicitly rely on enforcement or information problems for much of their motivation. E.g., William D. Andrews, A Consumption-Type or Cash Flow Personal Income Tax, 87 HARv. L. Rev. 1113 (1974); Michael J. Graetz, 100 Million Unnecessary Returns: A Fresh Start for the U.S. Tax System, 112 YaLE L.J. 261 (2002).

${ }^{35}$ See Richard M. Bird \& Eric M. Zolt, Redistribution via Taxation: The Limited Role of the Personal Income Tax in Developing Countries, 52 UCLA L. REv. 1627 (2005). 
The definition of the tax base is a central issue in tax policy. For example, we must decide whether to tax income or consumption, ${ }^{36}$ whether to tax corporate income at the entity level or to include it within the individual income tax base, ${ }^{37}$ and how and whether income earned abroad should be taxed. ${ }^{38}$ Each of these topics has generated an extensive literature.

At a somewhat narrower level, defining the base of an income tax is not easy. Our income tax system is incredibly complex, involving highly detailed rules about what is and is not subject to tax. Introductory tax and advanced tax policy classes grapple with the taxation of such items as home production, imputed income, capital gains, personal expense deductions, charitable donations, welfare benefits, tax shelters, and so on. The treatment of these items can have important effects on choices, such as whether second earners choose to work, whether individuals marry, whether they own a home, where they live, how much money they give to charitable organizations, and how they structure their savings.

To illustrate how the BETR can help us understand the proper scope of the tax base, consider "mixed business/personal" items. These are items that both serve a business purpose but also have a consumption element. The

${ }^{36}$ See William D. Andrews, A Consumption-Type or Cash Flow Personal Income Tax, 87 HaRv. L. Rev. 1113 (1974); Alvin C. Jr. Warren, Fairness and a Consumption-Type or Cash Flow Personal Income Tax Comments, 88 HaRv. L. Rev. 931 (1974); DAvid F. BRADFord, Fundamental IsSUES IN CONSUMPTION TAXATION (1996); Bankman \& Weisbach, supra note 14.

37 See U.S. Dep't of the Treas., Integration of the Individual and Corporate TaX Systems, TaXing Business Income Once (1992); Am. LaW Inst., Federal Income Tax Project: Integration OF THE INDIVIDUAL AND CORPORATE InCOME TAXES, REPORTER'S STUdy OF CORPORATE TAX INTEGRATION (1993).

${ }^{38}$ For a collection of articles on this topic, see MichaEL J. GRAETZ, Foundations of INTERNATIONAL INCOME TAXATION (2003). 
problem arises both on the deduction side (can an individual deduct an expense that has both personal and business elements?) and the inclusion side (must an individual include something of value that is received in part for business reasons?).

On the deduction side, business expenses are generally deductible while personal consumption expenditures are not deductible. Items that are a mixture of business and personal are difficult to characterize. For example, clothing purchased to wear to work has a business component but also often has a personal consumption component. ${ }^{39}$ Education increases future salaries and (one hopes) provides personal benefits.

On the income side, salary and most other benefits received by employees are taxable, but items of value that are closely tied to the business are not. For example, a fancy office has value to an employee but is not taxable. Similarly, business meals offer nourishment but are, for the most part, not taxable to employees. ${ }^{40}$

There are large literatures on both sets of issues: when mixed business/personal expenses should be deductible, ${ }^{41}$ and when mixed

39 See, e.g., Pevsner v. Commissioner, 628 F.2d 467 (5th Cir. 1981) (no deduction for clothing that taxpayer was required to buy for her job at a boutique clothing store).

40 Congress has largely dealt with the problem of business meals by limiting or denying deductions on the employer side. See I.R.C. § 274(n) (establishing a general rule that only $50 \%$ of meal expenses are allowed as a deduction); id. $\S 274(0)$ (no deduction for business meals provided to employees on employers' premises after December 31, 2025).

41 See, e.g., William A. Klein, Income Taxation and Commuting Expenses: Tax Policy and the Need for Nonsimplistic Analysis of "Simple" Problems, 54 CoRnEll REV 871 (1968); Boris I. Bittker, Income Tax Deductions, Credits, and Subsidies for Personal Expenditures, 16 J. L. EcoN. 193 (1973); Daniel I. Halperin, Business Deduction for Personal Living Expenses: A Uniform Approach to an Unsolved Problem, 122 U. PA. L. REV. 859 (1974); Thomas D. Griffith, Theories 
business/personal receipts should be taxed. ${ }^{42}$ The underlying problems, however, are quite similar. We illustrate the analysis by considering the treatment of commuting expenses. The same framework applies to other mixed items.

Commuting is a significant issue in modern life. According the Bureau of Transportation Statistics, workers in the United States spend, on average, slightly under an hour (25 minutes each way) commuting to work every day. ${ }^{43}$ Individually it is a big piece, and often the worst piece, of the daily

of Personal Deductions in the Income Tax, 40 Hastings L. J. 343 (1988); Louis Kaplow, The Income Tax as Insurance: The Casualty Loss and Medical Expense Deductions and the Exclusion of Medical Insurance Premiums, 79 CALIF. L. Rev. 1485 (1991); Louis Kaplow, Income Tax Deductions for Losses as Insurance, 82 Am. Econ. Rev. 1013 (1992); Wolfram F. Richter, Efficiency Effects of Tax Deductions for Work-Related Expenses, 13 InT'L TAX PUB. Fin. 685 (2006).

${ }^{42}$ See, e.g., Avery Katz \& N. Gregory Mankiw, How Should Fringe Benefits Be Taxed?, 38 NAT'L TAX J. 37 (1985); Callum Butler \& Paul Calcott, Optimal Fringe Benefit Taxes: The Implications of Business Use, 25 InT'L TAX PUB. FIn. 654 (2018); Yehonatan Givati, Googling a Free Lunch: The Taxation of Fringe Benefits, 69 TAX L. Rev. 275 (2016). For a general discussion, see Michael J Graetz \& Deborah H. Schenk, Federal Income Taxation Principles AND PoliCIES 103-129 (6th ed. 2002).

43 Commuting to Work, U.S. DeP'T of Transp., Bureau of Transp. Stat., https://www.bts.gov/content/commuting-work (last visited Sept. 22, 2019) (2013 statistics). Note that this average includes people who work at home. 
grind. ${ }^{44}$ Collectively, it is a very large expense. ${ }^{45}$ In addition to the time and money spent on it, commuting generates congestion, pollution, traffic accidents, and other public health costs. ${ }^{46}$

Should the cost of commuting to work be deductible? On the one hand, it is a cost of earning income: but for having a job, workers would not have to commute. Like other costs of earning income, it should, on this theory, be deductible. On the other hand, commuting is a personal consumption choice because it depends on where one chooses to live. It is a cost of having a home further from work. Personal consumption choices, such as costs of a house or apartment, are not deductible. On this theory, commuting is part of the cost of a home and should not be deductible. Commuting expenses are a mix of business and personal, and, therefore, present a difficult tax policy problem.

Notwithstanding their business element, U.S. tax law generally has not treated commuting expenses as deductible business expenses. ${ }^{47}$ The leading

${ }^{44}$ See Daniel Kahneman \& Alan B. Krueger, Developments in the Measurement of Subjective Well-Being, J. ECON. PERSP., Winter 2006, at 3, 13 tbl.2 (2006) (noting that in a study of working women in Texas, the morning commute was the daily activity with the lowest mean net affect).

45 See Kathryn Vasel, We Spend \$2,600 a Year Commuting to Work, CNN Money (June 17, 2015), https://money.cnn.com/2015/06/17/pf/work-commute-time-andmoney/index.html.

${ }^{46}$ See Jane E. Brody, Commuting's Hidden Cost, N.Y. Times: Well (Oct. 8, 2013), https://well.blogs.nytimes.com/2013/10/28/commutings-hidden-cost (summarizing research on the relationship between commuting and obesity, high blood pressure, heart disease, depression, anxiety, and other ailments).

47 This rule is found in Treas. Reg. 1.162-2(e), which provides in its entirety, "Commuters' fares are not considered as business expenses and are not deductible." 
case is Commissioner v. Flowers..$^{48}$ Flowers involved an individual who lived in Jackson, Mississippi, and had recently taken a job in Mobile, Alabama.

Flowers did not want to leave his home in Jackson, so he chose to commute 250 miles (by rail) to Mobile. The Commissioner denied Flowers a deduction for his commuting costs, and the Supreme Court upheld the Commissioner's decision. It reasoned that Flowers's commuting expenses "were incurred solely as the result of the taxpayer's desire to maintain a home in Jackson while working in Mobile." 49

Of course, one could equally well say that the expenses were solely the result of the taxpayer's work in Mobile. The Court's statement seems false on its face, and the Court does not say why it rejects the alternative, equally plausible view. Nevertheless, it is firmly established that commuting expenses are not deductible under U.S. tax law.

This is not the case universally. Among OECD countries, Austria, Belgium, Denmark, Finland, France, Germany, Luxembourg, Norway, Poland, Sweden, and Switzerland allow taxpayers to deduct commuting costs..$^{50}$ In addition, there are exceptions to the U.S. rule for cases where the business element is clearly dominant. For example, travel to work in temporary locations can

48326 U.S. 465 (1946).

${ }^{49} \mathrm{Id}$. at 473 .

50 See Michelle Harding, Personal Tax Treatment of Company Cars and Commuting Expenses: Estimating the Fiscal and Environmental Costs 39 tbl.14 (OECD Ctr. for Tax Pol'y \& Admin., OECD Taxation Working Paper No. 20, 2014), https://dx.doi.org/10.1787/5jz14cg1s7vl-en. 
sometimes be deductible. Business travel is similarly deductible (or if paid for by an employer, excludable). ${ }^{51}$

Somewhat in tension with this general rule, certain fringe benefits for commuting, so-called "qualified transportation fringes," are not taxable. ${ }^{52}$ These include transportation in a commuter highway vehicle for travel between the employee's residence and place of employment, transit passes, and qualified parking. ${ }^{53}$ Employers can even allow employees to elect to purchase these fringes by having their salary reduced, almost as if they were purchased in the market. ${ }^{54}$ The qualified transportation fringe rule makes these expenses effectively deductible, because an exclusion and a deduction have the same net effect on tax payments.

The December 2017 tax law changed the tax treatment of qualified transportation fringes, but it did so by eliminating the employer deduction for these benefits rather than by including the benefits in employee income. 55

51 For an overview, see Topic No. 511 Business Travel Expenses, InTERnAl REVEnUE SERV., https://www.irs.gov/taxtopics/tc511 (last updated Aug. 1, 2019).

52 See I.R.C. $§ 132$ (f). In 2019, there was a cap of \$265 per month each for vehicles and parking (with the amount adjusted for inflation each year). INTERNAL REVENUE SERV., Publication 15-B: Employer's TAX Guide to Fringe BenEFITS For USE In 2019, at 21 (Dec. 18, 2018).

53 A similar fringe benefit for bicycle commuting expenses has been discontinued from 2018 to 2025. See I.R.C. $\$ 132(f)(8)$.

54 See I.R.C. § 132(f)(4).

55 See I.R.C. $\S \S 274(\mathrm{a})(4), 274(1)$. Bicycling fringes were given a different treatment. These fringes remain deductible to the employer because of section 274(1)(2), but-as noted above-are now taxable to the employee. See supra note 53. It is not clear why Congress singled out bicycles for different treatment, particularly given that the treatment may 
That is, qualified transportation fringes remain, for the most part, not taxable to employees but at the same time employers cannot deduct their cost. This effectively, although not precisely, has the effect of taxing qualified transportation fringe benefits to employees. If an employer is taxed at the same rate as an employee, denying a deduction to the employer is equivalent to taxing the employee. ${ }^{56}$ It is not precisely the same because employer and employee tax rates will most often not be the same. If the employer rate is above the employee rate, then the denial of an employer deduction results in a higher effective tax rate than if the employer deduction were allowed and the employee were taxed. If the employer rate is below the employee rate, the result is a lower effective rate.

The basic tradeoffs in the taxation of commuting expenses were laid out in a 1968 article by William Klein. ${ }^{57}$ Our discussion will build on two examples that Klein uses, though we modify the numbers for arithmetic ease. First, we will imagine a taxpayer who has a job in the city and is choosing whether to live in the city or the suburbs. ${ }^{58}$ All else equal, the individual is indifferent between living in the city and the suburbs, so she will live where

sometimes be better and sometimes be worse. For a discussion of the 2017 tax law's qualified transportation fringe reforms, see Julie Roin, The Case for (and Against) Surrogate Taxation (Univ. of Chi. Law Sch., Pub. Law Working Paper No. _, Sept. 20, 2019), https://ssrn.com/abstract=3456923.

56 To see this, we need to compare three possible treatments: (1) a deduction to the employer and tax to the employee; (2) a deduction to the employer and no tax to the employee (old law) and (3) no deduction and no tax (current law). If we consider a payment of, say, $\$ 100$ and assume that both the employer and the employee are taxed at the same rate, say 20\%, comparing the results of (1) and (3) shows that they are the same and are more highly taxed than (2).

${ }^{57}$ Klein, supra note 41 , at 879-83.

58 See id. at 880-81. 
it is cheapest..$^{59}$ She will pay $\$ 80$ more per month in rent if she chooses to live in the city rather than the suburbs, but she will pay $\$ 100$ more per month in commuting costs if she chooses to live in the suburbs rather than the city. Absent taxes, the choice would be clear: live in the city and save, on net, $\$ 20$. This is the efficient choice: the additional resource cost of living in the city (\$80 extra in rent) is less than the additional resource cost of living in the suburbs ( $\$ 100$ extra in commuting costs).

Now bring taxes into the picture. Assume that the individual's marginal income tax rate is 30 percent and that commuting expenses are deductible but rent is not. Instead of choosing between $\$ 80$ in rent and $\$ 100$ in commuting costs, the individual now faces a choice between $\$ 80$ in rent and $\$ 70$ in (after-tax) commuting costs (i.e., $\$ 100$ in out-of-pocket costs less a deduction of \$30). The deduction for commuting expenses distorts the individual's choice in this example, causing her to live in the suburbs when without taxes, she would live in the city. Without the deduction, there would be no distortion.

Klein's second example (which, again, we will modify) involves an individual whose home is fixed and who is choosing between two jobs. ${ }^{60}$ The job that is further from home pays an extra $\$ 100$ per month, but it requires her to incur an extra $\$ 80$ in commuting costs. Again, absent taxes, the choice would be clear: take the job, as the wage increase $(\$ 100)$ exceeds the increase in commuting expenses $(\$ 80) .{ }^{61}$

${ }^{59}$ Alternatively, we might interpret Klein's costs as reflecting his welfare rather than monetary costs, so that the individual chooses to live where the welfare costs are lowest.

${ }^{60}$ See id. at 881-83.

61 We will assume that the individual derives no disutility from commuting except for the cost. Perhaps she enjoys listening to audiobooks en route or she commutes by public transit and can read happily on the bus or train. 
Now bring taxes into the picture once again. We still will assume that the marginal income tax rate is 30 percent, but this time, commuting expenses are not deductible. Instead of a choice between $\$ 80$ in extra commuting costs and $\$ 100$ in higher pre-tax wages, the individual faces a choice between $\$ 80$ in commuting costs and $\$ 70$ in higher after-tax wages ( $\$ 100$ less a $\$ 30$ tax). Now it is the lack of a deduction for commuting costs that causes the individual to make the inefficient choice, rejecting the farther-away job with the higher wage. Note also that if commuting costs were deductible, there would be no distortion: the individual would choose the farther-away job with the higher wage. ${ }^{62}$

Why do Klein's examples come out this way? The key idea is that in the first example, the individual was trading off commuting costs against an after-tax consumption expense (rent). To avoid distorting that choice, we need to treat commuting costs and rent the same way. In the second example, the individual was trading off commuting costs against a pre-tax item of income (wages). Since she discounts pre-tax income by her tax rate, we must also encourage her to discount her commuting costs by her tax rate.

Klein concludes that there is no easy way to determine whether the first or second example is a more accurate description of reality. ${ }^{63}$ We sometimes choose homes and jobs simultaneously and other times in different sequences. Moreover, as Klein notes, administrability concerns also factor into the choice among policy options. ${ }^{64}$ It might be that a deduction that varies in proportion across different classes of taxpayers could minimize the inefficiency that arises from distorting housing and work choices. But any

${ }^{62}$ She would be $\$ 20$ better off in pre-tax terms and would pay additional taxes of $30 \% \mathrm{x}$ $(\$ 100-\$ 80)=\$ 6.67$.

${ }^{63}$ See id. at 883.

${ }^{64}$ See id. at 894. 
such benefit must be weighed against the administrative and compliance costs that a more complex policy would entail.

The BETR provides a possible path toward resolving the problem-one that incorporates tax-inducted distortions and enforcement costs into a single measure. The BETR asks that we consider a small change in the tax rule, such as a marginal increase in the deduction for commuting expenses. The change in resources resulting from the marginal change in the law is the net revenue from behavioral changes less any change in administrative or mechanical compliance costs.

To illustrate: Start from the default position under U.S. tax law of no deduction. (We will ignore for now the qualified transportation fringe provisions.) A marginal increase in the deduction for commuting costs will make commuting slightly cheaper. Because commuting costs affect both housing and work choices, we should expect movement along both margins. We can expect a small shift toward longer commutes. Housing and work locations will shift away from each other because commuting between them is cheaper.

Because the starting position was one of no deductibility, the individuals who adjust their housing choices in light of the new rule will be individuals who previously were indifferent between a shorter and longer commute. Imagine, for example, an urban worker who previously faced a choice between $\$ 100$ extra in rent if she lived in the city and $\$ 100$ extra in commuting costs if she lived in the suburbs. A very small deduction for commuting costs causes her to move from the city to the suburbs, but 
because she was previously indifferent, the shift does not affect her utility or the resources available to society. 65

Now imagine a worker who previously was indifferent between a job close to home and a job farther away that paid $\$ 100$ per month more but required her to incur $\$ 70$ in extra commuting costs. Assume, as above, a 30 percent tax rate. A small deduction for commuting causes the individual to shift from the lower-paying to higher-paying job. Again, there is no firstorder effect on the job-switcher's utility (she is, after all, approximately indifferent between her two employment options), but the government gains roughly $\$ 30$ in extra tax revenue when the job-switcher's taxable income rises by $\$ 100.66$

Summing up the two effects, moving from a starting position of no deduction for commuting expenses to a very small deduction for commuting expenses has an unambiguously positive effect on taxable income (the emphasis of the ETI). ${ }^{67}$ Importantly, though, the BETR is concerned not with

${ }^{65}$ In addition, there may be a shift to spending more on commuting, such as for fancier cars. But like with a shift in housing location, there is no first-order effect of this change on the taxpayer's utility and-starting from a zero tax rate-no tax effect.

${ }^{66}$ Roughly $\$ 30$ rather than exactly $\$ 30$ because we must subtract out the very small cost of the deduction.

${ }^{67}$ It is perhaps unintuitive that increasing an allowable deduction leads to an increase in taxable income. The analysis is parallel to the discussion of a reduction in labor income taxes in the first example in Part I. On the margin, there is an increase in work effort (in the earlier example) or work productivity (in the case of commuting expenses), leading to an increase in taxable income. In both cases, there may be a loss of revenue due to a "transfer" effect, which arises because the lower tax rate (in the case of an income tax) or the increased deduction (for commuting) lowers taxes on activities that do not change. For the same reasons that we do not count transfers in the income tax example (and therefore concluded that a lower tax rate increases resources), a marginal increase in the deduction for 
the effect on taxable income but with the effect on revenue resulting from behavioral changes less administrative and mechanical compliance costs. Requiring millions of taxpayers to track and report commuting expenses in order to claim a very small deduction would no doubt increase compliance costs. Processing and potentially auditing those deduction claims would increase administrative costs. The BETR instructs us to compare the revenue gains from alleviating the work distortion against the associated administrative and compliance costs. Only if the former benefits outweigh the latter set of costs would a move toward a small deduction for commuting expenses add to total resources.

The above analysis assumed we were starting at the U.S. position of complete nondeductibility. Suppose instead that commuting expenses are partially deductible, and we are considering a small increase in the deduction. Once again, the change in the law affects both margins: work and housing. The analysis of the effects on work is the same: there is no firstorder effect on individual taxpayers' utility but there will be an increase in tax revenues from the change in work productivity (i.e., individuals choosing higher-paying jobs). Housing, however, is different. As before, there is no first-order effect on individual taxpayers' utility from the shift in location, but now there is a revenue loss from longer (or more expensive) commutes.

To illustrate, suppose we already allow a deduction for half of commuting expenses. Again, let us assume a 30 percent tax rate. Thus, an urban worker will be indifferent between paying $\$ 85$ extra in rent to live in the city or $\$ 100$ extra in commuting costs to live in the suburbs. The $\$ 100$ out-of-pocket commuting expense will entitle the worker to a deduction worth $\$ 15$ (i.e., $\$ 100 \times 50 \%$ x 30\%), leaving her in equipoise between city and suburban living.

commuting increases resources (starting from a baseline of no deductibility and before considering administrative and compliance costs). 
Now assume that we slightly increase the deduction for commuting expenses. The only individuals whose housing choices change will be individuals who previously were indifferent between city and suburban living. Again, there is no first-order effect on the individual taxpayer's utility. But this time, when the taxpayer switches from living in the city to living in the suburbs, the government loses (slightly more than ${ }^{68}$ ) \$15 in tax revenue. The revenue losses from taxpayers moving to the suburbs (or, more generally, choosing longer and more expensive commutes) must be weighed against the revenue gains from taxpayers switching to farther away and higher paying jobs.

Leaving aside enforcement (i.e., administrative and compliance costs), the optimal rule sets the revenue loss from behavioral changes on the housing side of the analysis to equal the revenue gain from behavioral changes on the work side. We have already seen that a no-deduction rule cannot be justified on efficiency grounds except by virtue of administrative and compliance costs. Interestingly, the complete-deduction rule followed by many other OECD countries probably cannot be justified on any efficiency grounds. This is because a small decrease in the deduction (e.g., shifting to a deduction for 99 percent rather than 100 percent of commuting costs) would have a positive, first-order effect on revenue resulting from housing choice changes but only a second-order negative effect on revenue resulting from a reduction in work productivity. Moreover, the administrative and compliance costs of dialing back an existing deduction are likely to be much smaller than the administrative and compliance costs of introducing an

68 Slightly more than $\$ 15$ rather than exactly $\$ 15$ because now slightly more than $50 \%$ of commuting costs are deductible. 
entirely new deduction. (In the first case, the only cost is the trivial expense of multiplying by 99 percent.) ${ }^{69}$

Without more data, the BETR cannot resolve-once and for all-the tax treatment of commuting expenses. It can, however, provide a framework for analysis. It tells us what variables we need to measure (changes in tax revenue resulting from behavioral changes, administrative costs, and mechanical compliance costs), and it tells us how to combine these variables into a single statistic that captures the efficiency consequences of a small policy change. Finally, it allows us to rule out options. Here, a complete deduction for commuting costs is almost certainly suboptimal, and a nodeduction rule is only optimal if administrative and compliance costs are high. ${ }^{70}$ Thus, even in contexts where we cannot reduce the BETR to a precise number, we can use the BETR to determine whether the status quo is suboptimal and whether a change in one direction is likely to enhance welfare.

${ }^{69}$ In a recent article, Alan Viard makes similar arguments in favor of a partial deduction for work-related expenses. See Alan Viard, Base Broadening Gone Wrong: Work-Related Costs and the TCJA, 164 TAX NoteS FED. 539 (July 22, 2019). Viard does not, however, invoke the ETI or the BETR.

${ }^{70}$ One way to understand our analysis of commuting costs is to recognize that commuting is an economic complement to work. Lowering the cost of commuting lowers the cost of work. A standard result in economics is that if we have a labor income tax, we should subsidize complements to work and tax substitutes. W. J. Corlett \& D. C. Hague, Complementarity and the Excess Burden of Taxation, 21 REv. ECon. STUD. 21 (1953). For an explanation of this result, see Louis KAPLOW, ThE THEORY of TAXATION AND PUBlic ECONOMiCS (2008). The reason is that these taxes and subsidies help offset the distortion in work effort from the tax on income. The positive BETR estimate for a commuting expense deduction reflects this intuition. 


\section{Tax Enforcement}

\section{A. Scope of the Problem}

Tax enforcement is a central problem in tax system design. Enforcement expenditures are substantial, and yet still a significant amount of income escapes taxation due to evasion or nonpayment. According to IRS data and estimates, enforcement costs associated with the federal income tax in the United States (including compliance costs and administrative costs) sum to nearly 9 percent of all federal income tax collections, or nearly 1 percent of gross domestic product. ${ }^{71}$ Meanwhile the net income tax gap (i.e., the amount of true income tax liability that ultimately goes uncollected) is nearly 19 percent of all income taxes, or more than 2 percent of GDP. ${ }^{72}$ Federal

${ }^{71}$ We derive these figures from the following sources: IRS researchers estimated in 2013 that income tax-related compliance costs topped $\$ 150$ billion. Marcuss et al, supra note 22. The IRS's expenditures in fiscal year 2013 were approximately $\$ 11.6$ billion. INTERNAL REvEnUe SERvice DaTa BooK, 2013, at 63 (2013), https://www.irs.gov/pub/irssoi/13databk.pdf. The IRS's income tax collections in fiscal year 2013 were $\$ 1.876$ trillion. Id. at 15 tbl.6. ( $\$ 150$ billion $+\$ 11.6$ billion $) / \$ 1.876$ trillion $\approx 8.614 \%$. U.S. gross domestic product in 2013 was approximately $\$ 17.083$ trillion. U.S. Dep't of Commerce, Bureau of Economic Analysis, Vintage History of Quarterly Gross Domestic Product (GDP) and Gross Domestic Income (GDI) Estimates (last updated July 26, 2019), https://www.bea.gov/data/gdp/gross-domestic-product/gdp-gdi-vintage-history. (\$150 billion $+\$ 11.6$ billion) $/ \$ 17.083$ trillion $\approx 0.949 \%$. Others estimate that compliance costs are even higher than the IRS calculates. See, e.g., Benzarti, supra note 22 (estimating that federal income tax filing costs and related compliance costs are approximately $1.2 \%$ of GDP).

72 For the most recent estimate of the U.S. federal income tax gap, see InTERnAL REvEnUE Serv., Federal Tax Compliance Research: Tax Gap Estimates for Tax Years 2008-10

(Publication 1415) (May 2016), https://www.irs.gov/pub/irs-soi/p1415.pdf. The estimated net tax gap for tax years 2008 to 2010 is $\$ 291$ billion for individual income tax and \$35 billion for corporate income tax. $I$ d. at 2 . Total income tax collections in fiscal year 2009 were \$1.416 trillion. See Internal Revenue Service Data Book, 2013, supra note 71, at 15 tbl.6. $(\$ 291$ billion $+\$ 35$ billion $) /(\$ 1.416$ trillion $+\$ 291$ billion $+\$ 35$ billion $) \approx 18.714 \%$. U.S. 
employment, estate and gift, and excise taxes as well as state and local taxes add to total enforcement costs, and substantial gaps between collections and true liabilities emerge for those taxes as well.

Cross-country comparisons are complicated by different data definitions, but the United States does not appear to be an outlier with respect to the enforcement costs of its tax system ${ }^{73}$ or its residual tax gap ${ }^{74}$ (either relative to GDP or to revenue). The challenge of closing the tax gap while managing enforcement costs is most acute in lower-income countries, where constraints on tax capacity are thought to be a significant obstacle to economic development.75 As Roy Bahl and Richard Bird explain, "a good internal tax system" is "an essential element in developing a capable state."76

Tax enforcement also plays a potentially important role in the emergence of within-country wealth inequality and in efforts to narrow the

gross domestic product in 2009 was approximately $\$ 14.628$ trillion. U.S. Dep't of Commerce, supra note 71. ( $\$ 291$ billion $+\$ 35$ billion) $/ \$ 14.628$ trillion $\approx 2.223 \%$.

${ }^{73}$ An OECD study found that the United States had sixth most efficient tax system among thirty advanced economies when measured by aggregate tax administrative costs as a percentage of net revenue collection. OECD, GovernMENT AT A GLANCE 2011 (June 2011), at 191 tb.58.1, https://www.oecd-ilibrary.org/efficiency-of-taxadministrations_5kg705q75nzt.pdf. Note, though, that this comparison does not include compliance costs.

${ }^{74}$ The estimated percentage of taxes owed that are not paid is higher in Italy $(27 \%$ to $30 \%$ ) than in the United States (16\%) but higher in the United States than in Sweden (9\%). See Fred Pampel, Giulia Andrighetto \& Sven Steinmo, How Institutions and Attitudes Shape Tax Compliance: A Cross-National Experiment and Survey, 97 Soc. ForCES 1337, 1337-38 (2018).

${ }^{75}$ For an overview, see Bahl \& Bird, supra note 2.

${ }^{76} I d$. 
gap between rich and poor. Gabriel Zucman and coauthors estimate that more than one-tenth of the increase in the share of net total household wealth held by the top 0.1 percent of U.S. households from 1980 to 2010 is attributable to an increase in offshore tax haven holdings. ${ }^{77}$ Of course, wealth that is hidden from tax authorities is extraordinarily difficult to measure with accuracy or precision, and the estimates of Zucman and his coauthors are disputed by other researchers. ${ }^{78}$ Yet this only further underscores the policy significance of tax enforcement. Gerald Auten and David Splinter-who conclude that the rise of wealth inequality in the United States has been much less dramatic than Zucman and his collaborators Thomas Piketty and Emmanuel Saez contend-arrive at their divergent assessment in large part because they disagree about the effectiveness of tax enforcement and the distribution of hidden wealth. ${ }^{79}$ Whichever set of authors is correct, their

77 See Annette Alstadsæter, Niels Johannesen, and Gabriel Zucman, Online Appendix to Who Owns the Wealth in Tax Havens? Macro Evidence and Implications for Global Inequality, 162 J. PuB. Econ. 162 (2018), http://gabriel-zucman.eu/offshore. Excluding offshore wealth, Alstadsæter et al. estimate that the wealth share of the top 0.1 percent increased by 10.6 percentage points from 1980 to 2010. Id. at tbl.A7b. Including offshore wealth, the authors estimate that the wealth share of the top 0.1 percent increased by 11.9 percentage points during that timeframe. Id. at tbl.A10b. $(11.9-10.6) / 11.9 \approx 10.9$.

${ }^{78}$ See Gerald Auten \& David Splinter, Income Inequality in the United States: Using Tax Data to Measure Long-Term Trends (Aug. 23, 2018) (unpublished manuscript), http://davidsplinter.com/AutenSplinter-Tax_Data_and_Inequality.pdf.

79 Piketty, Saez, and Zucman estimate that the share of pre-tax income flowing to the top 1 percent of U.S. households increased by 9.0 percentage points from 1979 to 2014 . Auten and Splinter put that figure at only 4.1 percentage points. Id. at 2. According to Auten and Spinter, " $[t]$ he most important reason our results differ from Piketty, Saez, and Zucman (2018) is our allocation of underreported income." Id. at 1 (citing Thomas Piketty, Emmanuel Saez \& Gabriel Zucman, Distributional National Accounts: Methods and Estimates for the United States, 133 Q. J. EcoN. 553 (2018)). 
disagreement highlights the first-order importance of tax enforcement to distributional debates.

In addition to its consequences for the distribution of income and wealth across households, tax enforcement can affect the allocation of labor and capital across sectors. This is because some sectors are likely to have greater evasion opportunities than others. To illustrate: For many years, it was much more difficult for states to enforce sales and use taxes on Internet purchases than on transactions at brick-and-mortar storefronts. In 2000, Austan Goolsbee estimated that nearly one quarter of consumers who purchased items on the Internet rather than at physical stores did so because of the taxevasion advantage of e-commerce. ${ }^{80}$

Tips provide a further illustration. Tips account for well under one-half of one percent of all reported income in the United States, ${ }^{81}$ but an estimated 10 percent of underreported income. ${ }^{82}$ The discrepancy arises from the fact

${ }^{80}$ See Austan Goolsbee, In a World Without Borders: The Impact of Taxes on Internet Commerce, 115 Q. J. Econ. 561, 562 (2000). A 2018 Supreme Court decision transformed the tax enforcement landscape, making it much easier for states to collect sales and use taxes from online sellers. South Dakota v. Wayfair, 138 S.Ct. 2080 (2018). Still, the case of ecommerce helps to emphasize the potential for tax enforcement (and nonenforcement) to have broad cross-sectoral impacts.

81 Compare Heidi Shierholz et Al., ECon. Pol’y InSt., EmPloyers Would Pocket \$5.8 Billion of Workers' Tips Under Trump Administration's Proposed 'Tip Stealing' Rule 3 (Dec. 14, 2017), https://www.epi.org/files/pdf/139138.pdf (estimating $\$ 32$ billion of tip income in 2016), with Internal Revenue Serv., Statistics of Income Div., Publication 1304 tbl.1.4 (2018) ( $\$ 10.379$ trillion of total income reported in tax year 2016).

82 "Understanding The Tax Gap And Taxpayer Noncompliance": Hearing Before the H. Comm. on Ways \& Means, 116th Cong. 1, 8 (2019), https://waysandmeans.house.gov/sites/democrats.waysandmeans.house.gov/files/docume nts/TIGTA\%20Testimony\%20FINAL\%2005-07-19.pdf (written testimony of J. Russell George, Treasury Inspector Gen. for Tax Admin.). 
that cash tips are not subject to comprehensive third-party reporting regimes. ${ }^{83}$ We likely see more businesses operating on a cash basis and compensating employees via cash tips because these sectors are effectively subsidized through tax nonenforcement.

The effects of tax enforcement and nonenforcement extend across international boundaries. For example, the U.S. financial sector has to compete with offshore financial institutions that enjoy evasion opportunities unavailable here. ${ }^{84}$ While not the only reason for offshore accounts, tax evasion is likely an important driver of their use. Tax evasion may, therefore, alter where and how the financial sector functions. ${ }^{85}$

There is, not surprisingly, a large literature modeling and empirically estimating how taxpayers respond to enforcement strategies. The literature includes detailed behavioral models attempting to understand the interactions among various policies. For example, we might want to know how a change in the audit rates affects evasion levels. Does it reduce evasion because people are more afraid of getting caught, or might it actually increase evasion as taxpayer seek to keep more of their money in light of the higher enforcement (akin to an income effect when prices go up)? The

${ }^{83}$ Id. at 2,

${ }^{84}$ Jim Himes reports that tax havens have very large portfolio investments relative to their population. See James R. Hines Jr., Treasure Islands, 24 J. Econ. PERSP. 103, 106 tbl.2 (2010). For example, the Cayman Islands has the sixth largest portfolio capital inflow in the world with a population of less than 47,000 people, similar to a medium-size American city.

85 Gabriel Zucman estimates that, as of 2014, more than $\$ 6$ trillion of assets were held through tax havens. Gabriel Zucman, The Hidden Wealth of Nations: The SCOURge of TaX HAVENS 39 (2015). 
literature uses a variety of tools to identify and estimate these sorts of effects. ${ }^{86}$

The BETR acts as a complement to these modeling and estimation efforts. It helps us understand how the various consequences of enforcement efforts affect social welfare. In addition, the BETR helps us understand the goals of enforcement policy. What should we be maximizing when making enforcement decisions?

\section{B. The Conceptual Challenge}

While tax scholars have long understood that enforcement is a firstorder concern they have struggled to find a framework for comparing enforcement's benefits to its costs. Carl Shoup wrote nearly a half-century ago that "it might at first appear that money should be appropriated for tax administration until the incremental dollar of cost yielded just one dollar's increase in revenue," but "this would be to overlook the fact that in tax administration real resources are being used up to implement a system of transfer payments." ${ }^{87}$ Agnar Sandmo argued some years later that the government should invest in tax administration beyond the point that marginal revenue gains equal marginal costs (i.e., should spend $\$ 1$ to raise less than $\$ 1$ ), because the cost of tax evasion includes not only the revenue costs but also the disutility experienced by tax cheats who fear getting caught. ${ }^{88}$ Joel Slemrod and Shlomo Yitzhaki subsequently concluded that "[ $t]$ he increased revenue to be gained from increasing the enforcement of the law does not enter the [cost-benefit] expression because this is merely a

\footnotetext{
${ }^{86}$ For a survey of recent work, see Joel Slemrod, Tax Compliance and Enforcement: New Research and Its Policy Implications, 57 J. Econ Lit. 904 (2019).

${ }^{87}$ Carl Shoup, Public Finance 433 (1969).

${ }^{88}$ Agnar Sandmo, Income Tax Evasion, Labour Supply, and the Equity-Efficiency Tradeoff, 16 J. Pub. Econ. 265, 283 (1981).
} 
transfer among the economy's identical agents." 89 Public finance economists have continued to wrestle with the question in the years since..$^{90}$

Contrary to the above views, almost all of the literature modeling the tax enforcement problem takes the view that we should maximize net revenue. For example, Michael Allingham and Agnar Sandmo adopted Gary Becker's model of crime to the tax enforcement context. In their model, the government chooses a combination of audit rates and penalties to maximize net revenue, measured as tax receipts less the government's administrative costs. ${ }^{91}$ Modifications of the Allingham and Sandmo model take the same approach. Another line of literature takes a game theoretic approach to the problem. These models view enforcement strategies as taking place in an equilibrium where taxpayers choose reporting and other behaviors in response to audit strategies and audit strategies in turn respond to reporting. As with the Allingham and Sandmo line of models, the game theoretic models also seek to find equilibria audit strategies that maximize net revenue, defined the same way. ${ }^{92}$

${ }^{89}$ Slemrod \& Yitzhaki, supra note 31, at 188.

${ }^{90}$ For a review of the literature on tax enforcement, see Slemrod \& Yitzhaki, supra note 5.

${ }^{91}$ Michael G. Allingham \& Agnar Sandmo, Income Tax Evasion: A Theoretical Analysis, $1 \mathrm{~J}$. Pub. Econ. 323 (1972).

${ }^{92}$ J.F. Reinganum \& L. Wilde, Income Tax Compliance in a Principal-Agent Framework, 26 J. Pub. Econ. 1, 5 (1985). E.g., I. Sanchez \& J. Sobel, Hierarchical Design and Enforcement of Income Tax Policies, 50 J. Pub. Econ. 345 (1993); Yulia (Paramonova) Kuchumova, The Optimal Deterrence of Tax Evasion: The Trade-off Between Information Reporting and Audits, 145 J. Pub. Econ. 162 (2017); H. Cremer, M. Marchand \& P. Pestieau, Evading, Auditing and Taxing: The Equity-Compliance Tradeoff, 43 J. PuB. Econ. 67 (1990); Suzanne Scotchmer, Audit Classes and Tax Enforcement Policy, 77 Am. Econ. Rev.: PAPERS \& Proc. 229 (1987), Maciej 
Outside of the academic literature, budgets for tax enforcement are also often justified via net revenue raised..$^{93}$ In a typical example, in February 2016 testimony before the Senate Finance Committee, then-IRS Commissioner John Koskinen justified a request for $\$ 18$ billion in additional funding over a 10-year period on the grounds that it would generate \$64 billion in additional revenue. ${ }^{94}$ His successor Charles Rettig has similarly argued that Congress should invest more in the IRS because the resulting revenues will exceed costs. ${ }^{95}$

The BETR sheds light on this question of what tax enforcement should seek to maximize. In particular, it provides a measure of the change in total resources from a marginal change in enforcement policy. The change in total resources is the change in revenue due to changes in behavior less any increases in administrative and mechanical compliance costs. An efficient enforcement policy sets this measure, the BETR, equal to zero for each enforcement choice. This means that the government seeking an efficient enforcement policy should not seek to maximize net revenue.

Kotowski, David Weisbach, and Richard Zeckhauser, Audits as Signals, 81 U CHICAGo L. REv. 179 (2014).

${ }^{93}$ Although outside of the sort of formal models found in the economics literature, people do not claim to be able to maximize revenue.

${ }_{94}$ IRS Budget and Current Operations: Hearing Before the S. Fin. Comm., 114th Cong. 2, 9 (2016), https://www.finance.senate.gov/imo/media/doc/2016\%20JAK\%20testimony\%20SFC\%20 on\%20FY17\%20budget\%20021016x.pdf (written testimony of John A. Koskinen, Comm'r, Internal Revenue Serv.).

95 "The 2019 Tax Filing Season and the 21st Century IRS": Hearing Before the S. Fin. Comm., 116th Cong. 1 (2019), https://www.finance.senate.gov/imo/media/doc/10APR2019RETTIG.pdf (written testimony of Charles P. Rettig, Comm'r, Internal Revenue Serv.). 
We explained the basic reasoning for this approach in Part I. We provide additional detail and examples in what follows. We start by focusing on traditional enforcement tools-audits, penalties, and reporting - and then turn to how the choice of the tax base interacts with enforcement.

\section{Audits, Penalties, Recordkeeping, and Reporting}

Start by considering audit and penalty strategies. We can think of the government setting an audit and penalty strategy as engaged in a game with imperfect information. It sets its strategy based on what it can observe about taxpayers. Taxpayers respond by adjusting what they report. The result is an equilibrium set of strategies. The government must choose a strategy to maximize social welfare given the information it has and its understanding of how taxpayers will respond to its strategy. The strategies, on both sides, can be complex and depend on the information available. ${ }^{96}$

There are an almost infinite number of ways that the government can change its auditing strategy, and taxpayer responses may be hard to predict. To make the problem tractable, we simplify it by assuming a uniform increase in the probability of audit and relatively simple responses by taxpayers to this increase in the audit rate. ${ }^{97}$ The audit rate in the United

${ }^{96}$ For example, increasing the threat of audit may induce taxpayers to report lower income rather than the expected higher income. See Joel Slemrod, Marsha Blumenthal \& Charles Christian, Taxpayer Response to an Increased Probability of Audit: Evidence from a Controlled Experiment in Minnesota, 79 J. PUB. ECon. 455 (2001).

97 This is a vast simplification because few taxpayers face the average audit rate. Instead, audit strategies are focused on particular types of taxpayers and depend on how taxpayers report items of income. The actual strategy is a closely guarded secret. Moreover, there is no clear definition of "audit." The government checks on the veracity of returns in a wide variety of ways, including matching information returns, letters sent to verify items, office visits in an IRS office, and full scale home searches. Changing the audit rate does not tell us which checks are changed or the intensity of the checks. 
States for fiscal year 2018 was approximately 0.5 percent of all tax returns, down from 0.8 percent a decade earlier. ${ }^{98} \mathrm{~A}$ number of commentators have argued that the declining audit rate is problematic because when audit rates are low, evasion will increase. ${ }^{99}$ Therefore, this simplified example captures some of what commentators think of as a plausible change in policy. More complex policies and responses would be analyzed similarly.

The key to understanding how the change in the audit rate affects total resources is to separate the mechanical and behavioral effects of the change. This is not always intuitive in the case of tax enforcement, and the line can be subtle.

Consider a taxpayer facing an increase in the probability of audit. She will change her behavior along a number of margins. For example, she may reduce evasion and report correspondingly higher income. ${ }^{100}$ She may spend more on compliance, double or triple checking her returns for accuracy because of the higher risk of audit. She may spend more to conceal her evasion or avoidance so that the new audits do not detect it. And she may change her work effort (or other elements of the tax base, such as savings)

${ }_{98}$ See Internal Revenue Serv., Internal Revenue Service Data Book, 2018, at 23 tbl.9a (May 2019), https://www.irs.gov/pub/irs-soi/18databk.pdf; Internal Revenue Serv., Internal Revenue Service Data Book, 2008, at 23 tbl.9a (Mar. 2009), https://www.irs.gov/pub/irs-soi/08databkrevised.pdf.

${ }^{99}$ See, e.g., Howard Gleckman, The IRS Audit Rate Is Plummeting. Does It Matter?, TAX POL'Y CTR.: TAX Vox (Apr. 2, 2018), https://www.taxpolicycenter.org/taxvox/irs-audit-rateplummeting-does-it-matter; Emily Horton, Underfunded IRS Continues to Audit Less, CTR. FOR BUdGET \& POL'y PRIORITIES: OFF THE CHARTS (Apr. 18, 2018), https://www.cbpp.org/blog/underfunded-irs-continues-to-audit-less.

100 Or perhaps instead, she will evade more and report less. For a theoretical and empirical demonstration of this possibility, see Slemrod, Blumenthal, and Christian, supra note 15 , at $476-81$. 
because an increase in the audit rate implicitly increases tax rates (holding all else constant).

These changes do not affect the taxpayer's utility and, therefore, do not affect social welfare (except insofar as they change tax payments). To illustrate why, recall our taxpayer from Part I who has a wage rate of $\$ 10$ per hour subject to a 30 percent tax rate. She can work or engage in leisure, and, as noted, under these assumptions, the value of her leisure time is $\$ 7$ per hour. If our taxpayer can also engage in evasion, the returns to evasion are similarly $\$ 7$ per hour. And if our taxpayer chooses to spend time on compliance or concealment, the returns to these activities are also $\$ 7$ per hour. For example, she may spend additional time making sure her return is correct. Given the probability of audit, the penalty rate, and the likelihood of a mistake on her return, she would spend an additional hour checking her return if and only if the expected savings are $\$ 7$. If the return were lower, she would be better off spending that time on leisure or working. The same would be true for additional time on concealment.

These shifts, may, however, affect revenue. For example, if she reports more, revenues go up, and so do total resources. Her reporting more initially seems like just a transfer: reporting more takes money from her pocket and gives it to the government, without necessarily changing how much she works. But in fact, it is an increase in resources because she was indifferent to reporting a little bit more before the change. She is no worse off but the government has more tax revenue.

There may also be mechanical effects. If our taxpayer is unlucky, she will face an audit even after she adjusts her behavior. Responding to the audit, even if she owes no additional tax, costs her time and money, making her worse off. These mechanical compliance costs reduce total resources. That money is gone. And if she owes additional taxes, she is also worse off. These mechanical tax payments are just transfers. That money ends up being held by the government. 
The government side follows. The government may get additional revenue from behavioral effects. As noted, this additional revenue increases total resources. The government must pay for the audits, and this reduces resources. Finally, the government may collect back taxes from the auditsthe mechanical revenue effect. These make the government better off and our taxpayer worse off. They are just transfers and do not affect total resources.

The overall effect on total resources of a change in the audit rate is, therefore, the sum of three things: (1) the additional revenue from behavioral changes such as changes to reporting or work effort; minus (2) additional audit costs incurred by the government; and minus (3) additional mechanical compliance costs incurred by taxpayers. Total resources go upand therefore, an increase in the audit rate may be warranted-when the sum of the three components is positive.

The same basic analysis applies to reporting and recordkeeping. Consider a small increase in recordkeeping requirements. For example, the government could require better documentation of the basis of stock that has been sold, of charitable contributions, of foreign bank accounts, of payments to babysitters, or of any number of other items. What are the effects of such a change on total resources?

On the taxpayer side, the additional recordkeeping will have a number of effects. It will cause taxpayers to shift their behavior away from the relevant activities because the additional recordkeeping requirements increase the cost of the relevant activities. From the taxpayer's perspective, they are like an additional tax. For example, if we increase the recordkeeping or reporting required for the sale of stock, taxpayers will sell stock less often because the cost of doing so has gone up. Similarly, if the government requires more records when paying babysitters, people will use babysitters less because the costs have gone up. They will shift from selling stock to holding it, and from babysitters to other childcare services (or fewer childcare services). 
These shifts can either increase or decrease revenues depending on the tax rates on the activities out of and into which taxpayers have shifted. For example, new recordkeeping requirements on charitable donations and foreign bank accounts may cause people to shift out of these activities and into higher-taxed activities, increasing revenue. New recordkeeping for stock sales may cause taxpayers to hold their stock longer, reducing revenue. Whichever direction it goes, the change in revenue reflects a change in total resources.

The new recordkeeping requirements also have mechanical effects. They mechanically increase compliance costs, reducing resources. Everyone who sells stock, hires a babysitter, or keeps a foreign bank account must spend more on compliance. The new recordkeeping requirements may also change the costs of audits. For example, they may reduce audit costs because the necessary records may now be readily available. This saves resources for both taxpayers and the government. Changes in audit effectiveness may also change the back taxes that the government discovers on audits. These payments are mere transfers and do not affect total resources.

The change in total resources from the new recordkeeping rule is the sum of these effects: the behavioral revenue effects less any net increase in administrative costs and the mechanical increase in compliance costs. As always, we do not count new revenues that do not arise from behavioral changes (i.e., transfers).

A key consideration in the literature on enforcement (generally, not just in tax) is risk aversion. ${ }^{101}$ The literature typically considers a harm-causing

101 Mitchell Polinsky \& Steven Shavell, The Optimal Tradeoff Between the Probability and Magnitude of Fines, 69 Am. ECoN. REv. 880 (1979); Mitchell Polinsky \& Steven Shavell, Enforcement Costs and the Optimal Magnitude and Probability of Fines, 35 J. L. EcoN. 133 (1992); Louis Kaplow, The Optimal Probability and Magnitude of Fines for Acts that Definitely 
activity such as polluting, where some individuals should not engage in the activity because their benefit is less than the harm and others should because their benefit is greater than the harm. The standard torts solution to this problem is to impose liability equal to harm. With liability equal to harm, only individuals whose benefit is greater than the harm will engage in the activity.

Suppose instead of a fixed liability, we have a probabilistic regime where we impose liability on only a fraction of individuals but correspondingly increase the sanction so that the expected sanction is still equal to harm. Gary Becker argued that in an analogous setting we should set the probability of sanction as low as possible and the sanction as high as possible to save enforcement costs. Later literature, however, noted that if we follow this strategy, we expose people to risk (either because adjudication may be inaccurate or because they continue to engage in the sanctioned behavior anyway). ${ }^{102}$ Disutility from additional risk is a cost to taxpayers but yields no corresponding benefit from the government. It is thus a loss to society. We do not, therefore, want to maximize fines and minimize the probability of sanction.

Although we did not mention risk and risk aversion above, these effects can arise in the present context. The costs of risk aversion can be thought of as a mechanical cost of evasion. To the extent that individuals face an increase in risk that is mechanical in nature (i.e., unrelated to behavioral changes), they are worse off in the same way that they are worse off with mechanical compliance costs. Therefore, similar to the conclusions for torts

Are Undesirable, 12 InT. Rev. L. Econ. 3 (1992); Louis Kaplow \& Steven Shavell, Accuracy in the Determination of Liability, 37 J. L. Econ. 1, 8-10 (1994). For a summary of the literature, see Mitchell Polinsky \& Steven Shavell, The Theory of Public Enforcement of Law, in 1 HANDBOoK OF LAW AND Economics 403 (Mitchell Polinsky \& Steven Shavell eds., 2007).

102 See Kaplow, supra note 101; Kaplow \& Shavell, supra note 101, at 8-10. 
and other areas of law, we may not want to minimize audits and maximize fines in the present context.

Estimating the inputs into the BETR-here, the increase in revenue resulting from behavioral changes and the costs to the public and private sectors of additional enforcement-will require empirical sophistication, and even the most sophisticated estimates will be only approximate. Note, though, that different parts of the federal government already produce similar estimates. The Congressional Budget Office, for example, estimates that an additional $\$ 1$ of spending on IRS enforcement will generate $\$ 4.20$ to $\$ 5.20$ in additional tax collections. ${ }^{103}$ The BETR would direct policymakers to ask what portion of this additional revenue is due to behavioral changes (and thus adds to the resources available to society) and what portion is attributable to mechanical effects (and thus constitutes a transfer). While the Congressional Budget Office does not report that breakdown, the figures that it does report reflect implicit estimates of mechanical and behavioral effects. The BETR would direct policymakers to consider not only the cost to the public sector of an additional $\$ 1$ devoted to enforcement (straightforwardly, $\$ 1$ ), but also the cost to the private sector (i.e., the costs borne by individuals and firms in responding to audits). Both the IRS and the Urban-Brookings Tax Policy Center have developed intricate models that generate broadly similar estimates of compliance costs associated with various features of the tax system. ${ }^{104}$

\section{Interaction with the Tax Base}

103 Congressional Budget Office, Options for Reducing the Deficit: 2019 to 2028, at 307 (Dec. 2018), https://www.cbo.gov/system/files/2019-06/54667-budgetoptions-2.pdf.

104 See Daniel Berger et al., Estimating the Effects of Tax Reform on Compliance Burdens, TAX POL'Y CTR. (May 9, 2018), https://www.taxpolicycenter.org/sites/default/files/publication/155252/estimating_the_ef fects_of_tax_reform_on_compliance_burdens_2.pdf. 
Enforcement policies cannot be determined on their own. Enforcement depends on what we are trying to tax and at what rates. ${ }^{105} \mathrm{~A}$ prominent example of this problem is the taxation of capital income. Investments can be made in many forms and in many places. Taxes on capital income cause taxpayers to shift how and where they make investments so that the return is less observable by the government. For example, taxpayers might shift from domestic bank accounts to bank accounts in tax havens which do not report earnings, or even the existence of the account, to the U.S. government. Spending more on enforcement (for example, making efforts to investigate what assets are held in foreign bank accounts) means we can more easily tax capital income.

Framed in terms of the BETR, a tax on capital income with low enforcement would have a highly negative BETR: when we raise the rate on capital income, individuals would shift away from forms of capital income that we can readily tax, generating a large behavioral revenue response. We might be able to reduce that response and increase the BETR by spending additional resources on enforcement. The stronger the enforcement, the more easily we can tax capital income, and the more we want to tax capital income, the more we need enforcement. Enforcement decisions and base and rate decisions have to be made simultaneously.

The BETR allows us to determine how to make this joint decision. We want set the rate and enforcement simultaneously so that the BETR is equal to zero-i.e., there are no more gains to be had from additional incremental changes.

105 The key paper making the connection between enforcement and the tax base is Joel Slemrod \& Wojciech Kopczuk, The Optimal Elasticity of Taxable Income, 84 J. PuB. Econ. 91 (2002). 


\section{Distribution and Limitations of the BETR}

In prior parts, we described the BETR and demonstrated how it can be used to inform policy decisions. This section discusses: (1) how the BETR relates to distributional concerns; (2) the treatment of transfers between individuals and the government under the BETR; (3) the treatment of transfers between private parties under the BETR; and (4) the use of the BETR to evaluate changes that are more than marginal. Many of these raise complex issues, and, because of space limitations, our analysis is preliminary.

\section{A. Distribution}

The BETR is a measure of the change in resources from a small change in policy. It does not tell us the distributional effects of the policy change (i.e., who benefits or bears burdens). Distribution, however, is the core concern of tax policy. If we did not care about the distribution of the tax burden, we could simply impose a uniform tax, known as a head tax, on all individuals. A head tax would be far simpler and create fewer economic distortions than an income tax. A head tax, however, would have unwelcome distributional effects because the poor would pay the same amount as the wealthy. We bear the costs of an income tax, or other distorting taxes, because of the distributional benefits.

In this section, we discuss how the BETR interacts with distributional concerns. We make four related points.

First, the BETR is a key input into choices about the extent of redistribution. Recall that the BETR tells us the change in resources when we change taxes. It tells us the costs of redistribution. We need to weigh these costs against the benefits when determining how much to redistribute.

If, for example, high tax rates lead to a substantial reduction in work effort or a substantial increase in sheltering, we will be less willing to redistribute, and vice versa if the effects are small. The BETR is a measure of these effects and, therefore, is a key input into distributional choices. In fact, 
recent economic literature shows that the optimal top tax rate can be expressed using a simple formula that depends on the elasticity of taxable income (which is a simplified version of the BETR), the distribution of earnings ability, and distributional preferences. ${ }^{106}$

Second, for any given distribution of utilities, we should want the mix of tax (and other) policies that is most efficient. If not, we can shift to a more efficient policy with the same distribution of utilities, generating a Pareto improvement. Nobody is worse off because utilities are the same but there is more revenue because we have increased the efficiency of our tax policies. Moreover, by picking the most efficient mix of policies, we can redistribute more. Using the most efficient mix of tax policies means that when we weigh the costs against the distributional benefits, we can get the most redistribution.

Third, the BETR tells us the optimal mix of explicit taxes and other policies (such as audits, penalties, recordkeeping requirements, and reporting mandates) for any given distribution of utilities. This is because the BETR is the change in the resources available to society for a change in policy. In mathematical terms, finding the optimal mix of policies for any individual or class of individuals while holding their utility fixed means simultaneously setting the BETR to zero for each policy choice, subject to constraint that utility does not go down. At the optimum, there is no possible

106 See Piketty, Saez \& Stantcheva, supra note 5, at 235 (equation 2); Thomas Piketty \& Emmanuel Saez, Optimal Labor Income Taxation, in 5 HandBook of Public Economics 391, 411 (equation 3) (Alan J. Auerbach et al. eds., 2013). In their simplest, base case, Piketty, Saez and Stantcheva express optimal top tax rate as $\tau=(1+a \cdot e)^{-1}$, where $a$ is a parameter reflecting the distribution of high-income individuals and $e$ is the elasticity of taxable income. (They subsequently extend their model to account for additional effects but the core formula keeps the same form.) Piketty and Saez derive a similar formula for the optimal linear income tax rate (which takes the same form but also includes a factor reflecting distributional preferences). 
policy change that would increase the total resources available to society while leaving everyone at least as well off before. (If there were, then the current mix of policies would not be the optimal one.)

To understand this reasoning in more detail, consider a relatively simple tax system, one based just on labor income. Assume, moreover, that the only two instruments we can use to raise more revenue are rate adjustments and audits. If we raise the tax rate, then we can expect individuals to make behavioral changes that reduce revenue (e.g., shifting from labor to household production and leisure, or from reporting to nonreporting). If we raise the audit rate, then we also can expect individuals to make behavioral changes: some individuals may shift from nonreporting to reporting (or, more broadly, from evasion to compliance) due to the deterrence effect of the additional audits, raising revenue. In addition, audits absorb resources, and the resource costs of audits reduce resources.

Suppose that the current mix is inefficient. To understand what we mean by "inefficient," imagine a single individual making, say, $\$ 1$ million a year. Assume that the millionaire already has optimized: she has allocated her time so that she is indifferent between an extra hour of work and an extra hour of leisure, and between reporting another dollar more or less on her tax return. By slightly elevating the probability that the millionaire will be audited, we raise a bit more (gross) revenue from her. This is a product of both behavioral and mechanical effects. The behavioral effect manifests when the millionaire reports marginally more income due to the deterrence effect of the higher audit rate (though she still may fail to report some). The mechanical effect arises because-in expectation-we are slightly more likely to detect underreporting and to collect back taxes and penalties from the millionaire. The government's net revenue is the sum of the mechanical and behavioral effects (both of which we will assume are positive here) minus the cost of the additional audit. The millionaire's utility declines by the amount of her mechanical payments plus any compliance costs she bears as a result of the extra audit. 
Now imagine that we compensate the millionaire for her loss of utility by reducing her tax rate. We reduce her tax rate just enough so that the combination of the additional audit and the tax cut leaves the millionaire exactly as well off as before. The reduction in the tax rate has two effects on government revenue. The first is mechanical: We collect an ever-so-slightly smaller share of every dollar that the millionaire previously earned and still does. The second is behavioral: By lowering the millionaire's tax rate, we induce her to reallocate a little of her time from household production and leisure to labor (or to shelter a little less), which raises her taxable income, and she pays tax on that extra income (albeit at the slightly lower rate that we have just set). Recall that-by construction —-the millionaire's utility remains exactly the same as before. ${ }^{107}$

If the old mix of tax rates and audits was inefficient because we set the tax rate too high and the audit rate too low, then this combination of an audit increase and a rate reduction will raise revenue on net (i.e., after subtracting the cost to the government of the additional audit). In that case, we should do it. The millionaire's utility is - again, by construction-exactly the same as before, and the government has more money, which it can use to provide additional public goods or can give back to taxpayers (including the millionaire herself). If the old mix of tax rates and audits was inefficient because we set the tax rate too low and the audit rate too high, then we should reverse the set of moves envisioned above. That is, we should raise the tax rate on the millionaire and lower the audit rate, which will increase net government revenue in combination. In either case, we should keep on adjusting tax rates and audit rates until we cannot raise any more revenue while holding the millionaire's utility constant.

107 This means that if the increase in the audit rate causes the millionaire to bear additional compliance costs, we must reduce the tax rate enough to compensate her both for those compliance costs and for the mechanical effect of the extra auditing. 
Note that this argument for the efficient mix of policies does not imply that tax rates, the definition of the tax base, or enforcement policies should be set without regard to distributional concerns. If we want to impose a high tax burden on, say, a wealthy individual, we will need a high tax rate, which in turn requires a high level of enforcement and a broad tax base. The same is true if we want a low burden on an individual: we will want to choose the combination of a low tax rate, tax base, and enforcement that is most efficient. The efficient mix of taxes and enforcement policies depends on the overall tax burden on the individual. ${ }^{108}$ The BETR is not independent of distributional concerns. Instead, given a distributional goal, the BETR tells us how best to achieve it.

Fourth, to find the optimal mix of policies, we should not evaluate each one individually with distributional aims in mind. ${ }^{109}$ For example, we would not want to audit rich people beyond the efficient level of audits merely because they are rich. Relative to an efficient audit policy, an inefficient audit policy reduces available resources while not improving distribution. We can do better by choosing an efficient audit policy. Recall again what "efficiency"

108 This effect comes out clearly in work by Joel Slemrod and Wojciech Kopczuk. They consider the combination of optimal linear income tax rate and optimal elasticity of taxable income. They show that as distributional preferences get stronger, tax rates and enforcement income move together-the tax rate goes up as does spending on enforcement to reduce the elasticity goes up. Slemrod \& Kopczuk, supra note 105.

109 Phrased differently, when determining the optimal mix of policies, we ought not assign different distributional weights to different individuals (i.e., a higher weight to lowerincome individuals) and then conduct a cost-benefit analysis of each policy applying those weights. Cf. Matthew D. Adler, Benefit-Cost Analysis and Distributional Weights: An Overview, 10 Rev. Envtl. Econ. \& Pol'y 264 (2016) (advocating the use of distributional weights). Instead, we should choose a distribution of utilities and find the most efficient mix of policies for that distribution through unweighted cost-benefit analysis. If we conclude that we want to redistribute more beyond that, we should restart the analysis with a more egalitarian distribution of utilities and then identify the most efficient mix of policies given that more egalitarian distribution. 
means in this context: a mix of policies is efficient if it maximizes the resources available to society for a given distribution of utilities. We may want to audit rich people a lot because doing so is part of the efficient mix of policies given the distributional choices we have made (e.g., we have chosen a closer-to-egalitarian distribution of utilities). But we do not want to audit them yet even more than the efficient amount because they are rich. If we want to redistribute more, we should choose whichever tool-higher tax rates, higher audit rates, etc.-accomplishes that redistribution most efficiently. ${ }^{110}$

\section{B. Transfers Between Individuals and the Government}

We assumed above that the BETR should not include mechanical transfers between individuals and the government. We provide our reasons here.

To explain our reasoning, it will be convenient to have a variable denoting the value of a dollar held by government relative to the value of a dollar held by private individuals. We will denote that value by $g$. If $g>1$, a dollar is worth more when held by the government than when held by individuals. Pure transfers from private parties to the government increase welfare. If $g<1$, a dollar held by the government is worth less than when held by private individuals. Pure transfers to the government reduce welfare. If $g=1$, a dollar is worth the same whether held by the government or by individuals. Pure transfers in this case have no effect on overall welfare.

With this notation, we make three points. First, the BETR can accommodate any value of $g$. To understand why, consider a small increase

110 Or to put the point more precisely: If we audit the rich person beyond the efficient level, it should not be because we want to redistribute more from the rich to the poor. (It may be, though, because we are retributivists who want to punish tax evaders for reasons beyond efficiency and income redistribution.) 
in the tax rate. As we discussed, the rate change will have two effects: it will cause individuals to work a little bit less, reducing revenues-the behavioral revenue effect-and it will increase taxes paid on the income that individuals earn nonetheless-the pure mechanical transfer. The BETR as we have framed it is just the behavioral effect. By treating the transfer as neither creating nor reducing value, we implicitly valued the money that was previously held by individuals the same as that money now held by the government, which means we set $g=1$. To value that money at more or less when shifted to the government, we need only to value the mechanical transfer at more than or less than $1 .{ }^{111}$

Second, in a number of central cases, $g$ should be set to be equal to $1 .^{112}$ The core intuition is that the government should balance the economic distortion caused by redistributive taxes with their distributional benefits. If it does so, the benefits and costs of raising one more dollar are equal, which implies that money is worth the same to the government as it is to individuals.

To illustrate this in more detail, consider a simple tax system that consists of a flat rate tax on labor income (e.g., everyone pays a tax equal to 20 percent of their labor income) and a uniform lump sum tax or rebate (i.e., everyone pays the same fixed amount to the government or receives the same fixed amount from the government). Let $k$ represent the lump-sum component (with a positive value reflecting a payment to the government

111 Note that the ETI implicitly sets $g=1$ and cannot readily accommodate changes. Recall that the ETI measures the change in total resources from a change in tax policy by multiplying the change in taxable income by the tax rate. Changes in mechanical transfers appear nowhere in the analysis. Thus there is no change-in-revenue term to multiply by a value of $g$ that differs from unity.

$112 \mathrm{~A}$ number of authors have noted the conclusion in the text. The most recent statement of this conclusion is Bas Jacobs, The Marginal Cost of Public Funds Is One at the Optimal Tax System, 25 InT'L TAx PUB. Fin. 883 (2018). 
and a negative value a receipt from the government); let $t$ represent the tax rate; and let $y$ represent each taxpayer's income. Thus, each taxpayer transfers $k+$ ty to the government.

Holding revenue constant, we can trade off between $k$ and $t$. We can increase $k$ and decrease $t$ or vice versa. Increasing $k$ and reducing $t$ reduces distortion because $k$ is lump sum, but it also reduces the redistributive effects of the tax. Correspondingly, reducing $k$, and increasing $t$ increases distortion but has redistributive benefits. At the optimum, we will want to set $k$ and $t$ so that the marginal effects balance out. We want the marginal benefit of increased redistribution via $t$ to equal the marginal cost of distortion. If this is not true, we can increase overall welfare by increasing one and reducing the other.

What does this imply for the valuation of pure transfers to or from the government? Transfers change government spending, so we want to know what the argument above implies for the value of changes to government spending. At the optimum, the government should increase spending so that the benefit of spending an additional dollar on public goods is equal to the cost of raising that dollar. If the benefit of providing additional public goods exceeds the cost of raising the additional revenue, the government can raise welfare by spending more and taxing more. If the benefit of providing additional public goods is less than the cost, the government can increase welfare by spending less and taxing less.

In our simple tax system, the government can change its tax revenue by changing the lump sum component, $k$. If it does so, the change in revenue has no efficiency costs because it is lump sum. What if the government instead changes $t$ ? For the reasons stated above, the effects are the same as changing $k$. Therefore, even if the government raises additional revenue by increasing a distorting tax on labor income (or reduces revenue by reducing a distorting tax), the social cost of the revenue is the same as the cost of lump sum revenue, or 1 . As a result, an additional dollar spent on public goods should have a value of 1 . That is, $g=1$ at the optimum. 
The tax system considered above was quite simple, consisting of just a single tax rate and a uniform tax or rebate on all individuals, but the argument extends to a number of other cases. For example, if the rate schedule has more than one bracket, the same analysis applies. It also applies if the rate schedule is not set optimally as long as we can make offsetting adjustments for any change in rates along the lines suggested above. ${ }^{113}$ In a range of central cases, $g=1$.

The argument above assumes that lump sum taxes are an available and adjustable policy instrument. While the United States does not impose a head tax of the type imagined, it is not difficult to imagine the United States using a lump sum-like instrument. To illustrate, suppose that we seek to raise $\$ 30$ billion through a lump sum-like tax. There are around 300 million individuals in the United States, so we would need to raise $\$ 100$ from each person. Explicit lump sum tax assessments may not be acceptable, ${ }^{114}$ but the equivalent could be achieved indirectly. For example, we could reduce refunds by $\$ 100$ for everyone receiving a refund and add a $\$ 100$ charge to taxpayers who have underwithheld. Those who do not pay taxes but do receive Social Security could have their payments reduced by $\$ 100$. For those

113 For example, if we can hold the distribution of utilities fixed, then we should assume that $g=1$. To see why, imagine that we adopt a policy that raises more revenue from all taxpayers. We will have reduced the utility of all taxpayers. To leave everyone at least as well off as they were under the initial distribution of utilities, we will have to make changes somewhere else that have the effect of offsetting that utility loss (e.g., spending the money on public goods). This only increases welfare if a dollar spent by the government on public goods generates more utility than a dollar consumed by an individual, or if $g>1$. But if $g>1$, then we should continue to collect more revenue and spend more until there are no additional gains to be had, at which point $g$ will be 1 .

114 The government of British Prime Minister Margaret Thatcher infamously introduced a tax along these lines in Scotland in 1989 and in England and Wales in 1990. Political backlash was fierce; Thatcher faced a successful leadership challenge from within her own party; and the government her successor, John Major, rescinded the measure in 1991. See Peter Smith, Lessons from the British Poll Tax Disaster, 44 NAT'L TAX J. 421 (1991). 
not covered by income taxes or Social Security, we could adjust transfer payments such as Supplemental Nutrition Assistance Program (SNAP), reducing them by $\$ 100$. If we wanted to move in the opposite direction (i.e., reduce the lump-sum component by $\$ 30$ billion), policy options would be even more straightforward. We could send everyone a $\$ 100$ check. If that turns out not to be feasible, we could make changes elsewhere (e.g., a new $\$ 100$ per person refundable tax credit, a $\$ 100$ increase in benefits for Social Security recipients who do not claim the tax credit, an extra \$100 in SNAP benefits for individuals not covered by either of the previous two changes). The government thus has a large number of options that would approximate small increases or reductions in the lump sum component. As a result, the model considered above with a lump sum tax as a possibility may better reflect reality than a model that entirely rules out lump sum taxes.

Third, if the assumptions for $g=1$ do not hold, there is no general value of $g$ that holds in all or most cases. The appropriate value of $g$ will depend on the circumstances. It may be hard to know the value of $g$ even in specific cases. For example, one of the assumptions in the argument made above for setting $g=1$ was that the government appropriately trades off lump sum (non-redistributive but non-distorting) taxes with redistributive but distorting taxes. If the government is not doing so, we need to understand why before determining the appropriate value of $g .115$

115 We should emphasize as well that while debates about the size of government and the optimal amount of redistribution are often ideological, the value of $g$ does not have obvious ideological valence. For example, $g$ could be greater than 1 because we think that the government should spend more (and thus the marginal value of an additional dollar of government spending is greater than 1). Or $g$ could be greater than 1 because we think that the government should redistribute less (and thus a dollar of revenue from the lump sum tax can reduce reliance on redistributive taxes). Most people who think that the government should spend more $(g>1)$ also think that the government should redistribute more $(g<1)$, and most people who think that the government should spend less $(g<1)$ also think that the 
In particular, once the government is no longer choosing taxes appropriately, it may not be doing other things appropriately. It may spend too much or too little or on the wrong projects. If this is the case, the guidance that one gives the government may have to change completely. That is, the very idea that the BETR can be used to determine wise policies assumes that the government is capable of acting on that information. Once we drop that assumption, we need a much more contextual and detailed model to understand how to shift the government toward wise policies. Simply adjusting the value of $g$ is not likely to be nearly enough.

\section{Transfers to Private Parties and Externalities}

The prior section discussed transfers between individuals and the government. A related but distinct issue is transfers within the non-public sector, such as person-to-person gifts and charitable donations. ${ }^{116}$ The BETR, as formulated, does not adequately account for transfers among private parties.

We can illustrate the problem with an example. Suppose that we increase the existing tax rate by a small amount. As discussed above, individuals will react by adjusting their work, their reporting, and so forth. The individual may also react by donating a bit more to charity because when tax rates go up, the benefit of the charitable deduction goes up. To put numbers on it, suppose that the individual is subject to a 30 percent tax rate and responds to a marginal increase in the tax rate by donating $\$ 1$ more dollar to charity. As before, there is no first-order effect on the individual's welfare and there

government should redistribute less ( $g>1$ ). Given that most people (though not all people) hold beliefs suggesting that $g>1$ and that $g<1$, assuming that $g=1$ is not a bad place to start.

116 For a formal discussion of how transfers affect the elasticity of taxable income measure, see Chetty, supra note 5. 
is a reduction in tax revenue of $\$ 0.30$ (plus a small amount reflecting the rate increase which increases the value of the deduction), netting to an efficiency loss of $\$ 0.30$. Unlike in the cases discussed above, however, the individual's actions benefit a third party, the charity. The charity gains $\$ 1$. The social gain is the benefit to the charity less the behavioral revenue loss or, $\$ 1.00-\$ 0.30$ $=\$ 0.70$. If we ignored the transfer to the charity, we would have incorrectly concluded that the tax rate increase lead to a social loss of $\$ 0.30$.

The same analysis applies to any transfer between individuals because of taxation. At the margin, the donor is indifferent to transferring $\$ 1$ more, but the recipient is better off. We can think of transfers as positive externalities: a third party benefits from an individual's actions. The BETR, as formulated above, does not capture positive externalities. For similar reasons, it does not capture negative externalities.

In the section above considering transfers to the government, our focus was on the mechanical effect of changes to tax policies. Here, the focus is on the behavioral effect. The individual in our example is indifferent between donating one more dollar to the charity or not, but the charity gained the dollar, which is what generated the social gain. The mechanical effect of the tax change is the increase in the value of the tax deduction for existing donations. It is a transfer between the individual and the government, not a transfer between the individual and the charity.

To adjust the BETR to account for transfers, we must separately include the transfer. In the charitable donation example above, the BETR, as formulated in prior sections of the paper, would tell us that the increase in the tax rate results in a social loss of $\$ 0.30$. We then need to separately add in any transfers among private parties. The same holds for any externality (e.g., changes in emissions or congestion resulting from changes in commuting).

Separately adding in transfers among private parties and other externalities makes the application of the BETR somewhat more complicated. The ETI and the BETR are both attempts to have a single, relatively simple 
measure of the resource effects of changes in tax policy. Separately accounting for transfers and externalities means that these measures do not fully achieve their goal. Nevertheless, there is considerable data on the elasticity of charitable donations to changes in tax rates, so the data should be available to make the necessary adjustments on that front. ${ }^{117}$ In other cases (e.g., changes in emissions resulting from changes in commuting), the challenge of putting a price on externalities for purposes of the BETR will not be qualitatively different from the challenge of externality pricing in non-tax regulatory spheres.

\section{More-Than-Marginal Changes}

We have emphasized throughout that the BETR is a measure of the change in total resources resulting from a marginal change in policy. We can also use the BETR to analyze changes in policy that are more than marginal. In these cases, the BETR will not provide us with a precise estimate of the change in total resources resulting from the change in policy, but it can allow us to establish an upper or lower bound on the efficiency effects of the nonmarginal policy change.

The key assumptions that allow us to use the BETR to estimate upper or lower bounds on the efficiency effects of non-marginal policy changes are that any taxpayer who changes her or his behavior in response to a decrease in taxes is at least as well off as she was before, and that any taxpayer who changes her or his behavior in response to an increase in taxes is no better off than she was before. Armed with those assumptions, we will be able to estimate a lower bound on the change in resources resulting from a non-

117 Transfers to private parties other than charities also complicate the application of the BETR if they come at the expense of tax payments (e.g., in the wealth transfer tax context). For a treatment of related issues, see generally Louis Kaplow, Tax Policy and Gifts, 88 Am. ECon. REv. 283 (1998). We defer consideration of the application of the BETR to wealth transfer taxes for future analysis. 
marginal tax reduction (including reductions in enforcement) as well as an upper bound on the change in resources resulting from a non-marginal tax increase (including intensifications of enforcement).

To illustrate: Consider a taxpayer earning $\$ 10$ per hour and facing an initial tax rate of 30 percent. If a reduction in the tax rate from 30 percent to 20 percent (a non-marginal change) causes that taxpayer to work an additional hour, then we know that the taxpayer's opportunity cost of an additional hour of labor (i.e., the value to her of an additional hour of leisure) is at least $\$ 7$ and no more than $\$ 8$. If it is less than $\$ 7$, then she would have worked the additional hour even when the tax rate was 30 percent. If it is more than $\$ 8$, then she will not work the additional hour even when the tax rate is 20 percent. The effect on revenue resulting from the taxpayer's behavioral change (working an additional hour) is $\$ 2$ (i.e., the new 20 percent tax rate $\mathrm{x} \$ 10$ ), and the taxpayer is personally better off by somewhere between $\$ 0$ and $\$ 1$, plus any mechanical transfers. The BETR thus gives us a lower bound on the change in total resources resulting from the tax reduction.

Similar logic allows us to conclude that the BETR will give us an upper bound on the change in total resources resulting from a tax increase. Consider the same taxpayer earning $\$ 10$ per hour and facing an initial tax rate of 30 percent, but now imagine that the tax rate is raised from 30 percent to 40 percent (again, a non-marginal change). If the taxpayer works one fewer hour as a result of the tax hike, then we can infer that her opportunity cost of an additional hour of labor is at least $\$ 6$ and no more than $\$ 7$. Leaving aside mechanical transfers (which are offset by equivalent gains to the government), the taxpayer is worse off by somewhere between $\$ 0$ and $\$ 1$. The BETR here (which will be negative, because the behavioral change causes the government to lose money) will be an upper bound on the change in total resources resulting from the tax increase.

Many questions in tax law and policy involve continuous changes along a spectrum: what rate of tax to impose on an item; what percentage of costs in 
a certain category should be deductible; how many audits to perform; what level to set monetary penalties; and so on. In these cases, we can-in theory-use the BETR to find the optimal policy because the optimum is the point at which a marginal change in either direction yields a BETR of zero. 118 Other questions in tax law and policy involve discrete choices: e.g., whether a particular instrument should be classified as debt or equity, or whether a certain type of organization should be eligible for section 501(c)(3) exempt status. ${ }^{119}$ When tax policy involves choices across sharp lines rather than along sliding scales, the BETR can aid analysis by guiding us toward upperbound or lower-bound estimates where previously we had little guidance at all.

To illustrate, imagine that we are deciding whether to impose a new criminal penalty for tax evasion where previously the only penalty was civil. Here, we do not realistically have the option of making only marginal changes; a penalty cannot be 99.99 percent civil and 0.01 percent

118 In practice, there will likely be a limit on the number of marginal adjustments a tax authority can make, and so the tax authority will not have the option of finding the optimum through an iterated search process. Finding the optimal policy without an iterated search, however, will require structural assumptions about the relevant elasticities. In particular, elasticities estimated under current policies may not hold when policies diverge from the status quo. For example, the BETR for an increase in the tax rate from 20.00 percent to 20.01 percent may not be the same as the BETR for an increase in the tax rate from 20.99 percent to 30.00 percent. We therefore will have to make assumptions about whether and how the relevant elasticities change to determine optimal policies.

119 In these latter cases, the discrete policy choice could in theory be rendered continuous: while we do not typically treat instruments as 99 percent debt or treat organizations as 99 percent exempt, we conceivably could. See Edward Fox \& Jacob Goldin, Sharp Lines and Sliding Scales in Tax Law, TAX L. REv. (forthcoming), https://ssrn.com/abstract=3339656. 
criminal. ${ }^{120} \mathrm{We}$ cannot assume that every taxpayer who changes her evasion behavior as a result of the new criminal penalty was previously indifferent between evading and not evading. Some of the behavior-changers may have been inframarginal evaders who switched to truthful reporting because of the significant difference between a civil and criminal penalty.

Still, the BETR can substantially assist our analysis. Imagine that the change in tax revenue resulting from the new criminal penalty less administrative costs less mechanical compliance costs yields a negative number. Then we can rule out the possibility that the proposed penalty will be efficiency-enhancing. ${ }^{121}$ If we are moving in the opposite direction (i.e., eliminating a criminal penalty where previously there was one), then the analysis is symmetrical: the BETR provides us with an estimate of the change in total resources on the assumption that none of the individuals who switch from truthful reporting to evasion as a result of eliminating the penalty are made better off by the change. If the BETR for that policy change is negative, then we cannot say for sure whether the policy change is efficiencyenhancing or not, but if the BETR is positive, then we know that the actual efficiency gains are even greater.

\section{Conclusion}

Building on insights from the past quarter century of public finance scholarship, this article has presented a new, unified framework for evaluating a broad range of tax-related policies, including the definition of the tax base, the setting of tax rates, and the calibration of enforcement mechanisms. This framework-which we have called the Behavioral

120 We can, to be sure, have gradations of criminal penalties (e.g., misdemeanor vs. felony, different statutory minima and maxima, and so on).

${ }^{121}$ Some still may argue for the new criminal penalty on other grounds (e.g., retribution), but efficiency alone will not be a sufficient reason for the change. 
Elasticity of Tax Revenue approach-measures the efficiency consequences of policy changes the affect tax collections by altering taxpayer behavior. While the yardstick for the BETR is efficiency, defined capaciously as the maximization of real resources available to society, the BETR also serves a critical function in distributional decisionmaking. By revealing the resource cost of redistribution through different channels, the BETR can guide policy choices regarding the quantity of redistribution and the most efficient means of achieving specific distributional objectives.

Although all the applications of the BETR in this article have focused on the tax domain, nothing about the BETR depends on whether a particular policy is labeled as "tax." A wide array of "non-tax" policies will likewise affect the state's ability to collect tax revenue, including the specification of the number of property rights available in a legal system; the size of cash currency denominations recognized as legal tender; the statute of frauds and other recordkeeping requirements imposed by contract law; and the public provision of labor complements such as state-subsidized child care and commuter transportation. In each of these cases, adjustments to policy parameters will affect taxpayers at the margin between labor and leisure activity or between reporting and not reporting income to tax authorities. Everything we say here about the application of the BETR to tax policies will apply to non-tax policies affecting tax collections as well.

The extension of the BETR to non-tax policies is-we think-an important path for future research, and a forthcoming companion paper will examine the implications of the BETR for property law, contract law, labor law, and a number of other areas. The BETR, we believe, will help to clarify the relationship between tax and legal rules-a topic of intense interest and controversy in legal scholarship in recent years. Ultimately, the BETR will illustrate the importance of evaluating tax and non-tax rules through a single lens rather than allowing artificial labels to constrain legal and economic analysis. 


\section{Oxford University Centre for Business Taxation Working Paper series recent papers}

WP 20/04 Daniel Shaviro What are Minimum Taxes and Why Might One Favor or Disfavor Them?

WP20/03 Aqib Aslam and Alpa Shah Tec(h)tonic Shifts: Taxing the "Digital Economy" WP20/02 Ronald B. Davies, Dieter F. Kogler and Ryan Hynes Patent Boxes and the Success Rate of Applications

WP20/01 Richard Collier, Alice Pirlot and John Vella Tax policy and the COVID-19 crisis

WP19/16 Alice Pirlot Don't blame it on WTO law: An analysis of the alleged WTO law incompatibility of Destination-Based Taxes

WP19/15 Irem Güçeri and Maciej Albinowski Investment Responses to Tax Policy under Uncertainty

WP19/14 David R. Agrawal and David E. Wildasin Technology and Tax Systems

WP19/13 Alice Pirlot Exploring the Impact of European Union Law on Energy and Environmental Taxation

WP19/12 Michael Devereux How should business profit be taxed? Some thoughts on conceptual developments during the lifetime of the IFS

WP19/11 Sarah Clifford and Panos Mavrokonstantis Tax Enforcement using a Hybrid between Self- and Third-Party Reporting

WP19/10 Miguel Almunia, Irem Guceri, Ben Lockwood, Kimberley Scharf More giving or more givers? The effects of tax incentives on charitable donations in the UK

WP19/09 Itai Grinberg Stabilizing "pillar one" corporate profit reallocation in an uncertain environment

WP19/08 Joel Slemrod, Obeid Ur Rehman, Mazhar Waseem Pecuniary and non-pecuniary motivations for tax compliance: evidence from Pakistan

WP19/07 Enda Hargaden, Barra Roantree Does statutory incidence matter? Earnings responses to social security contributions

WP19/06 Lucie Gadenne, Tushar K. Nandi, Roland Rathelot Taxation and supplier networks: evidence from India 
WP19/05 Thiess Buettner, Boryana Madzharova Unit sales and price effects of preannounced consumption tax reforms: micro-level evidence from European VAT

WP19/04 Katarzyna Bilicka, Yaxuan Qi, Jing Xing Debt reallocation in multinational firms: evidence from the UK worldwide debt cap

WP19/03 Reuven Avi-Yonah, Orli Avi-Yonah, Nir Fishbien and Haiyan Xu Bridging the redblue divide: a proposal for US Regional Tax Relief

WP19/02 Elizabeth Gugl, George R. Zodrow Tax competition and the efficiency of "benefitrelated" business taxes

WP19/01 Michael P Devereux, Alan Auerbach, Michael Keen, Paul Oosterhuis, Wolfgang Schön and John Vella Residual profit allocation by income

WP18/22 Ronny Freier, Martin Simmler and Christian Wittrock Public good provision, commuting and local employment

WP18/21 Christian Wittrock Localization Economies and the Sensitivity of Firm Foundations to Changes in Taxation and Public Expenditures

WP18/20 Nadine Riedel, Martin Simmler and Christian Wittrock Local fiscal policies and their impact on the number and spatial distribution of new firms

WP18/19 Leonie Hug and Martin Simmler How cost-effective is public R\&D in stimulating firm innovation?

WP18/18 Wiji Arulampalam and Andrea Papini Tax Progressivity and Self-Employment Dynamics

WP18/17 Wiji Arulampalam, Michael P Devereux and Federica Liberini Taxes and the Location of Targets

WP18/16 Frank M Fossen, Ray Rees, Davud Rostam-Afschaf and Viktor Steiner How do Entrepreneurial Portfolios Respond to Income Taxation

WP18/15 Sebastian Beer, Ruud de Mooij and Li Liu International Corporate Tax Avoidance: A Review of the Channels, Magnitudes and Blind Spots

WP18/14 Daisy Ogembo Are Presumptive Taxes a Good Option for Taxing Self-Employed Professionals in Developing Countries

WP18/13 Ilan Benshalom The Rise of Inequality and the fall of Tax Equity

WP18/12 Thomas Torslov, Ludwig Weir and Gabriel Zucman The Missing Profits of Nations 
WP18/11 Andrea Lassman and Benedikt Zoller-Rydzek Decomposing the Margins of Transfer Pricing

WP18/10 Travis Chow, Jeffrey L Hoopes and Edward L Maydew US Firms on Foreign (tax) Holidays

WP18/09 Claudio Agostini, Juan Pablo Atal and Andrea Repetto Firms Response to Tax Enforcement through Audits

WP18/08 Mazhar Waseem Information, Asymmetric Incentives or Withholding? Understanding the Self-Enforcement of Value-Added-Tax

WP18/07 Matthew Smith, Danny Yagan, Owen Zidar and Eric Zwick Capitalists in the twenty-first century

WP18/06 Daniel Shaviro The new non-territorial U.S international tax system

WP18/05 Eric M Zolt Tax Treaties and Developing Countries

WP18/04 Anne Brockmeyer, Marco Hernandez, Stewart Kettle and Spencer Smith Casting a wider tax net: Experimental evidence from Costa Rica

WP18/03 Ruud de Mooij and Li Liu At a cost:the real effects of transfer pricing regulations WP18/02 Rita de la Feria Tax fraud and the rule of law

WP18/01 Eddy Hiu Fung Tam Behavioural response to time notches in transaction tax: Evidence from stamp duty in Hong Kong and Singapore

WP17/19 Michael P. Devereux, Giorgia Maffini and Jing Xing Corporate tax incentives \& capital structure: New evidence from UK firm-level tax returns

WP17/18 Sarah Clifford Taxing Multinationals beyond borders: financial and locational responses to CFC rules

WP17/17 Dominik von Hagen and Axel Prettl Controlled foreign corporation rules and crossborder M\&A activity

WP17/16 Marie Lamensch Destination based taxation of corporate profits - preliminary findings regarding tax collection in cross-border situations

WP17/15 Li Liu Tim Schmidt-Eisenlohr and Dongxian Guo International transfer pricing and tax avoidance: Evidence from linked trade-tax statistics in the UK.

WP17/14 Katarzyna Habu How much tax do companies pay in the UK? 
WP17/13 Katarzyna Habu How aggressive are foreign multinational companies in reducing their corporation tax liability?

WP17/12 Edward D. Kleinbard The right tax at the right time

WP17/11 Aaron Flaaen The role of transfer prices in profit-shifting by U.S. multinational firms: Evidence from the 2004 Homeland Investment Act

WP17/10 Ruud de Mooij and Li Liu At a cost: The real effect of transfer pricing regulations on multinational investments

WP17/09 Wei Cui Taxation without information: The institutional foundations of modern tax collection

WP17/08 John Brooks The definitions of income

WP17/07 Michael P. Devereux and John Vella Implications of Digitalization for International Corporation Tax Reform

WP17/06 Richard Collier and Michael P. Devereux The Destination-Based Cash Flow Tax and the Double Tax Treaties

WP17/05 Li Liu Where does multinational investment go with Territorial Taxation

WP17/04 Wiji Arulampalam, Michael P Devereux and Federica Liberini Taxes and Location of Targets

WP17/03 Johannes Becker and Joachim Englisch A European Perspective on the US plans for a Destination based cash flow tax

WP17/02 Andreas Haufler, Mohammed Mardan and Dirk Schindler Double tax discrimination to attract FDI and fight profit shifting: The role of CFC rules

WP17/01 Alan Auerbach, Michael P. Devereux, Michael Keen and John Vella Destinationbased cash flow taxation

WP16/14 Anzhela Cédelle The EU Anti-Tax Avoidance Directive: A UK Perspective

WP16/13 Michael Devereux Measuring corporation tax uncertainty across countries:

Evidence from a cross-country survey

WP16/12 Andreas Haufler and Ulf Maier Regulatory competition in capital standards with selection effects among banks

WP16/11 Katarzyna Habu Are financing constraints binding for investment? Evidence from natural experiment 
WP 16/10 Li Liu and Ben Lockwood VAT notches, voluntary registration and bunching: Theory and UK evidence

WP 16/09 Harry Grubert and Roseanne Altshuler Shifting the burden of taxation from the corporate to the personal level and getting the corporate tax rate down to 15 percent

WP 16/08 Margaret K McKeehan and George R Zodrow Balancing act: weighing the factors affecting the taxation of capital income in a small open economy

WP 16/07 Michael P Devereux and Li Liu Stimulating investment through incorporation

WP 16/06 Stephen R Bond and Irem Guceri R\&D and productivity: Evidence from large UK establishments with substantial R\&D activities

WP16/05 Tobias Böhm, Nadine Riedel and Martin Simmler Large and influential: firm size and governments' corporate tax rate choice?

WP16/04 Dhammika Dharmapala The economics of corporate and business tax reform

WP 16/03 Rita de la Feria EU VAT principles as interpretative aids to EU VAT rules: the inherent paradox

WP 16/02 Irem Guceri Will the real R\&D employees please stand up? Effects of tax breaks on firm level outcomes

WP 16/01 Giorgia Maffini, Jing Xing and Michael P Devereux The impact of investment incentives: evidence from UK corporation tax returns

WP 15/33 Anzhela Cédelle Enhanced co-operation: a way forward for tax harmonisation in the EU?

WP 15/32 James Mahon and Eric Zwick Do experts help firms optimise?

WP 15/31 Robin Boadway, Motohiro Sato and Jean-François Tremblay Cash-flow business taxation revisited: bankruptcy, risk aversion and asymmetric information

WP 15/30 Martin Simmler Do multinational firms invest more? On the impact of internal debt financing and transfer pricing on capital accumulation

WP 15/29 Daniel Shaviro The crossroads versus the seesaw: getting a 'fix' on recent international tax policy developments

WP 15/28 Zhonglan Dai, Douglas A Shackelford, Yue (Layla) Ying and Harold H Zhang Do companies invest more after shareholder tax cuts? 
WP 15/27 Martin Ruf and Julia Schmider Who bears the cost of taxing the rich? An empirical study on CEO pay

WP 15/26 Eric Orhn The corporate investment response to the domestic production activities deduction

WP 15/25 Li Liu International taxation and MNE investment: evidence from the UK change to territoriality

WP 15/24 Edward D Kleinbard Reimagining capital income taxation

WP 15/23 James R Hines Jr, Niklas Potrafke, Marina Riem and Christoph Schinke Inter vivos transfers of ownership in family firms

WP 15/22 Céline Azémar and Dhammika Dharmapala Tax sparing agreements, territorial tax reforms, and foreign direct investment

WP 15/21 Wei Cui A critical review of proposals for destination-based cash-flow corporate taxation as an international tax reform option

WP 15/20 Andrew Bird and Stephen A Karolyi Governance and taxes: evidence from regression discontinuity

WP 15/19 Reuven Avi-Yonah Reinventing the wheel: what we can learn from the Tax Reform Act of 1986

WP 15/18 Annette Alstadsæter, Salvador Barrios, Gaetan Nicodeme, Agnieszka Maria Skonieczna and Antonio Vezzani Patent boxes design, patents, location and local R\&D

WP 15/17 Laurent Bach Do better entrepreneurs avoid more taxes?

WP 15/16 Nadja Dwenger, Frank M Fossen and Martin Simmler From financial to real economic crisis: evidence from individual firm-bank relationships in Germany

WP 15/15 Giorgia Maffini and John Vella Evidence-based policy-making? The Commission's proposal for an FTT

WP 15/14 Clemens Fuest and Jing Xing How can a country 'graduate' from procyclical fiscal policy? Evidence from China?

WP 15/13 Richard Collier and Giorgia Maffini The UK international tax agenda for business and the impact of the OECD BEPS project

WP 15/12 Irem Guceri and Li Liu Effectiveness of fiscal incentives for R\&D: quasiexperimental evidence 
WP 15/11 Irem Guceri Tax incentives and R\&D: an evaluation of the 2002 UK reform using micro data

WP 15/10 Rita de la Feria and Parintira Tanawong Surcharges and penalties in UK tax law

WP 15/09 Ernesto Crivelli, Ruud de Mooij, Michael Keen Base erosion, profit-shifting and developing countries

WP 15/08 Judith Freedman Managing tax complexity: the institutional framework for tax policy-making and oversight

WP 15/07 Michael P Devereux, Giorgia Maffini and Jing Xing Corporate tax incentives and capital structure: empirical evidence from UK tax returns

WP 15/06 Li Liu and Ben Lockwood VAT notches

WP 15/05 Clemens Fuest and Li Liu Does ownership affect the impact of taxes on firm behaviour? Evidence from China.

WP 15/04 Michael P Devereux, Clemens Fuest and Ben Lockwood The taxation of foreign profits: a unified view

WP 15/03 Jitao Tang and Rosanne Altshuler The spillover effects of outward foreign direct investment on home countries: evidence from the United States

WP 15/02 Juan Carlos Suarez Serrato and Owen Zidar Who benefits from state corporate tax cuts? A local labour markets approach with heterogeneous firms

WP 15/01 Ronald B Davies, Julien Martin, Mathieu Parenti and Farid Toubal Knocking on Tax Haven's Door: multinational firms and transfer pricing 